\title{
Hydromorphologic Sorting of In- Stream Nitrogen Uptake Across Spatial Scales
}

\author{
Ute Risse-Buhl, ${ }^{1 *}{ }_{\odot}$ Christine Anlanger, ${ }^{1,2} \odot$ Christian Noss, ${ }^{2,3} \odot$ \\ Andreas Lorke, ${ }^{2} \odot$ Danielvon Schiller, ${ }^{4} \odot$ and Markus Weitere ${ }^{1} \odot$
}

\begin{abstract}
${ }^{1}$ Department River Ecology, Helmholtz Centre for Environmental Research GmbH - UFZ, Brückstraße 3a, 39114 Magdeburg, Germany; ${ }^{2}$ Institute for Environmental Sciences, University of Koblenz-Landau, Fortstrasse 7, 76829 Landau, Germany; ${ }^{3}$ Federal Waterways Engineering and Research Institute, Kussmaulstrasse 17, 76187 Karlsruhe, Germany; ${ }^{4}$ Department of Evolutionary Biology, University of Barcelona, Av. Diagonal 643, 08028 Barcelona, Spain
\end{abstract}

\begin{abstract}
Nitrogen $(\mathrm{N})$ uptake is a key process in stream ecosystems that is mediated mainly by benthic microorganisms (biofilms on different substrata) and has implications for the biogeochemical fluxes at catchment scale and beyond. Here, we focused on the drivers of assimilatory $\mathrm{N}$ uptake, especially the effects of hydromorphology and other environmental constraints, across three spatial scales: micro, meso and reach. In two seasons (summer and spring), we performed whole-reach ${ }^{15} \mathrm{~N}$-labelled ammonium injection experiments in two montane, gravel-bed stream reaches with rifflepool sequences. $\mathrm{N}$ uptake was highest in epilithic biofilms, thallophytes and roots (min-max range $0.2-545.2 \mathrm{mg} \mathrm{N} \mathrm{m}^{-2} \mathrm{day}^{-1}$ ) and lowest in leaves, wood and fine benthic organic matter (0.05$209.2 \mathrm{mg} \mathrm{N} \mathrm{m}^{-2}$ day $^{-1}$ ). At the microscale, $\mathrm{N}$ uptake of all primary uptake compartments except wood was higher in riffles than in pools. At the
\end{abstract}

Received 20 December 2019; accepted 5 October 2020;

published online 8 December 2020

Electronic supplementary material: The online version of this article (https://doi.org/10.1007/s10021-020-00576-7) contains supplementary material, which is available to authorized users.

Authors contributions: U.R.-B., C.A., C.N., A.L., D.v.S. and M.W. designed the study. U.R.-B., C.A., and D.v.S. performed research and analysed data, and D.v.S. contributed new methods. U.R.-B. and M.W. wrote the paper with comments from C.A., C.N., A.L., and D.v.S

*Corresponding author; e-mail: ute.risse-buhl@ufz.de mesoscale, hydromorphology determined the distribution of primary uptake compartments, with fast-flowing riffles being dominated by biologically more active compartments and pools being dominated by biologically less active compartments. Despite a lower biomass of primary uptake compartments, mesoscale $\mathrm{N}$ uptake was 1.7-3.0 times higher in riffles than in pools. At reach scale, $\mathrm{N}$ uptake ranged from 79.6 to $334.1 \mathrm{mg} \mathrm{N} \mathrm{m}^{-2}$ day $^{-1}$. Highest reach-scale $\mathrm{N}$ uptake was caused by a bloom of thallopyhtes, mainly filamentous autotrophs, during stable low discharge and high light conditions. Our results reveal the important role of hydromorphologic sorting of primary uptake compartments at mesoscale as a controlling factor for reach-scale $\mathrm{N}$ uptake in streams.

Key words: spatial hierarchy; ammonium uptake; epilithic biofilms; filamentous autotrophs; hydromorphology; environmental constraints; collective properties.

\section{HighLIGHTS}

- Hydromorphologic sorting was an important factor affecting $\mathrm{N}$ uptake across spatial scales.

- Coverage of biologically more active compart- 
ments and $\mathrm{N}$ uptake was higher in riffles than in pools.

- Thallophytes bloomed at stable low discharge and high light, causing highest reach-scale $\mathrm{N}$ uptake.

\section{INTRODUCTION}

Lotic ecosystems are spatially heterogeneous and hierarchically organized with feedbacks occurring across spatial scales (Frissell and others 1986; Townsend 1996; Poole 2002). Small spatial scales include microhabitat $\left(\sim 10^{-1} \mathrm{~m}\right)$ and mesohabitat $\left(\sim 10^{\circ} \mathrm{m}\right)$ and large spatial scales include reach $\left(\sim 10^{1}-10^{2} \mathrm{~m}\right)$, segment $\left(\sim 10^{2} \mathrm{~m}\right)$ and catchment $\left(\sim 10^{3} \mathrm{~m}\right)$ (Frissell and others 1986). Key stream biogeochemical processes, such as nitrogen $(\mathrm{N})$ uptake, are typically quantified at the reach scale (Newbold and others 1981; Mulholland and others 2008), which is the spatial unit of a stream along which similar hydrologic conditions exist. Environmental drivers of reach-scale $\mathrm{N}$ uptake (for example, assimilatory uptake) have been extensively described for single reaches and for global cross-system comparisons (for example, Webster and others 2003; Hall and others 2009; Tank and others 2018). However, the spatial heterogeneity in reach-scale $\mathrm{N}$ uptake is far from being fully resolved ( $\mathrm{O}^{\prime}$ Brien and others 2007; Mulholland and others 2008). One reason for this lack of knowledge is the scale dependence of drivers or controlling factors influencing patterns and processes (Wiens 1989; Peters and others 2007). In-stream N uptake is primarily carried out by microbial communities forming biofilms (Battin and others 2016). Microbial cells within biofilm communities are about eight to nine orders of magnitude smaller than the reach scale. Small-scale, heterogeneous distribution of biofilm communities and their performed processes have implications at the reach scale (Palmer and Poff 1997; Cardinale and others 2002; Peipoch and others 2016). To resolve the dynamics of ecosystem function, it is crucial to identify the set of controlling factors that contribute to shape patterns and processes at each spatial scale.

Here, we develop a spatially explicit hierarchical approach on the control and manifestation of $\mathrm{N}$ uptake in lotic ecosystems (Figure 1). Mechanisms or configuration at smaller spatial scales manifest the process rates at the next highest scale (Figure 1, blue boxes and red arrows). At the same time, the features of the higher spatial scale provide constraints (set limits) on the magnitude of those same processes (Figure 1, blue boxes and green arrows).
Most of the biogeochemical activity in streams is associated with the benthic zone in three primary uptake compartments: (1) largely autotrophic biofilms on mineral surfaces (epilithon), (2) largely heterotrophic biofilms on leaves, small wood and fine benthic organic matter, and (3) macroscopic plant forms (thallophytes, including filamentous algae and bryophytes) (see Tank and others 2018). Hydrologic and hydraulic variability in time and space are important factors modulating processes in lotic ecosystems and act both, directly and indirectly (Hart and Finelly 1999; Biggs and others 2005). Small-scale flow variation directly shapes community composition and architecture of epilithic biofilms at the microscale, where biofilms shift towards increased autotrophy with increased flow (Risse-Buhl and others 2017; Risse-Buhl and others 2020). Moreover, hydraulic conditions at this scale enhance mass transfer towards the streambed (O'Connor and Hondzo 2008; Reidenbach and others 2010). Both, biofilm community composition (autotrophic versus heterotrophic dominance) and local flow variations, but also light and nutrients influence $\mathrm{N}$ uptake at the microscale (Kemp and Dodds 2002; von Schiller and others 2009; Tank and others 2018; Figure 1). Hot spots of $\mathrm{N}$ uptake are sites of highest hydraulic transport rates (Larned and others 2004; Simon and others 2004; Peipoch and others 2016). However, these hydraulic effects are complemented by hydromorphologic effects at the mesoscale. Hydrologic variations control the distribution of sediment particles and organic matter by erosion and deposition (Leopold and others 1964; Hart and Finelly 1999; Gordon and others 2004). The interaction between flow and bed morphology creates typical hydromorphologic habitats comprising shallow, fast flowing riffles and deep, slow flowing pools (Gordon and others 2004). Pools are sites were wood, smaller leaves and fine particulate organic matter accumulate, whereas larger leaves are mainly retained in riffles (Kobayashi and Kagaya 2008). We assume that this contrasting hydromorphology causes sorting of primary uptake compartments, with dead organic matter accumulating in pools and biofilms on mineral surfaces dominating riffles. We define this effect as hydromorphologic sorting of primary uptake compartments at the mesoscale (Figure 1). Finally, hydromorphologic processes at the reach scale are shaped by geomorphology and hydrologic flow variations at longer time scales (> year) determining a characteristic distribution of hydromorphologic habitats along stream reaches (Biggs and others 2005; Wohl 2013; Figure 1). 


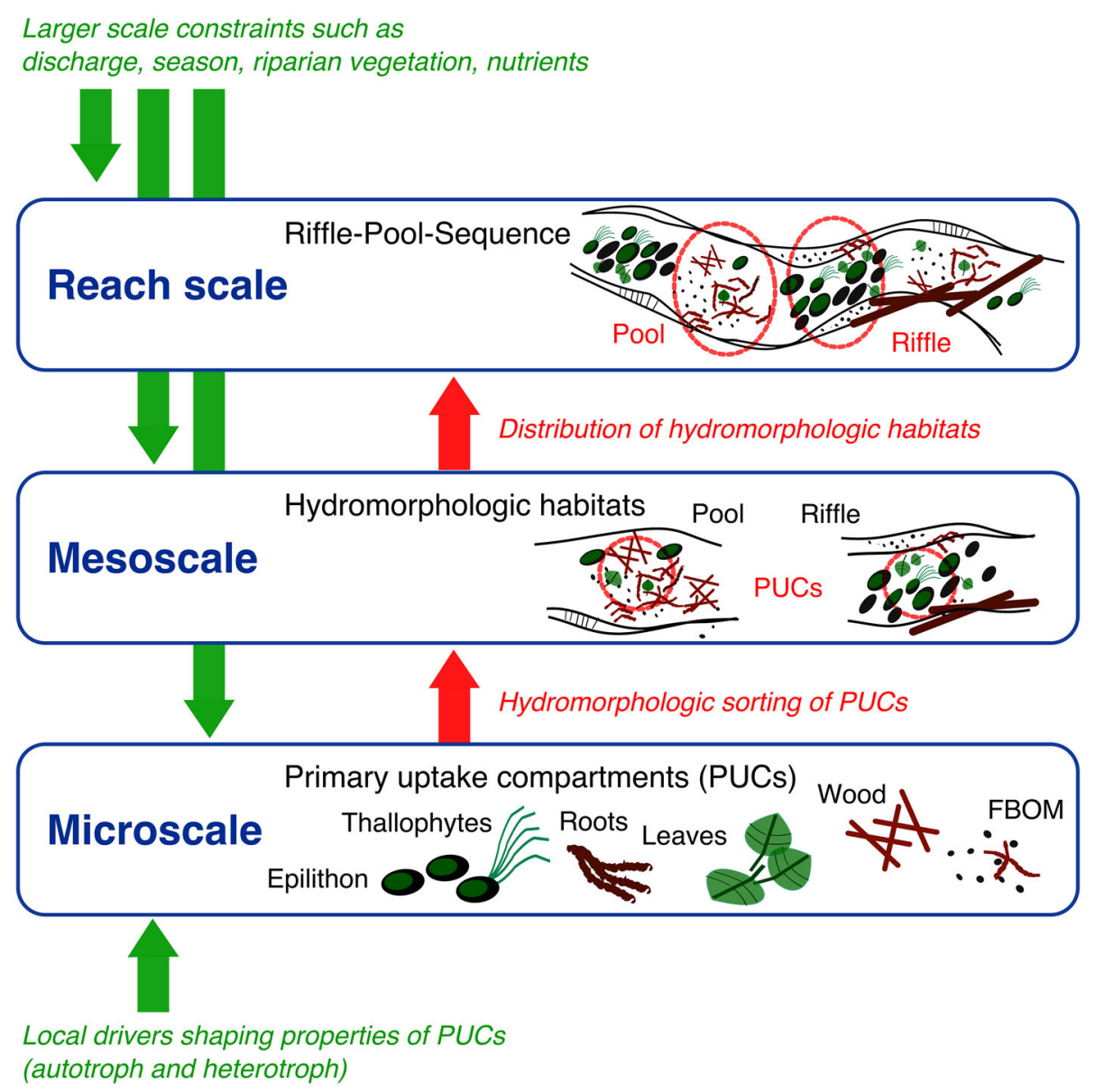

Figure 1. Concept of hierarchical spatial scales and driving factors of the distribution of $\mathrm{N}$ biomass and $\mathrm{N}$ uptake. Blue boxes indicate hierarchical spatial scales. Green arrows and text indicate constraints from larger scales and collective properties of smaller spatial scales to the next larger spatial scale. Red arrows and text indicate hydromorphologic control emerging from smaller spatial scales. PUCs-primary uptake compartments.

Because the magnitude of a function is constrained by the higher level of spatial organization as stated in hierarchy theory $\left(\mathrm{O}^{\prime} \mathrm{Neill}\right.$ and others 1986; Wu and Levin 1994), environmental drivers at each scale should be considered for a complete understanding of in-stream nutrient cycling (Drummond and others 2016). These environmental drivers, such as hydrologic and hydraulic variability, light availability or nutrient concentrations set constraints on and drive changes in biomass and structure of microbial communities and their process rates (Biggs and others 2005; Peipoch and others 2016).

The main goal of this study was to identify and to assess the factors that control the distribution of $\mathrm{N}$ biomass and $\mathrm{N}$ uptake of primary uptake compartments at three hierarchical spatial scales. We hypothesize that (1) $\mathrm{N}$ uptake at microscale is higher in riffles than in pools because the mass transfer towards the streambed is enhanced in the former due to higher mean flow velocity, (2) mesoscale $\mathrm{N}$ uptake is higher in riffles than in pools because hydromorphologic sorting accumulates biologically more active primary uptake compartments in riffles, and (3) reach-scale $\mathrm{N}$ uptake is higher in reaches with a larger contribution of riffles. In addition, we hypothesize that (4) largerscale constraints, such as hydrology (discharge) and season (light, dissolved nutrients), synchronously affect $\mathrm{N}$ uptake across all spatial scales.

\section{Materials AND Methods}

\section{Study Sites}

To address the emergent behaviour and environmental constraints on $\mathrm{N}$ uptake across the three spatial scales, we performed tracer injection experiments in two montane, gravel-bed streams with a characteristic riffle-pool sequence during two seasons (spring and summer). Our study de- 
sign allowed us to test for the consistency of our hypotheses across streams and contrasting environmental conditions within each stream. Over the scale of 490-580 $\mathrm{m}$ of stream length, we addressed reach-scale behaviour and used detailed sampling to distinguish hydromorphologic habitats, that is, riffles and pools, at the mesoscale and properties of primary uptake compartments at the microscale. The length of the study reaches was adequate for defining hydromorphologic habitats at the mesoscale (more than 20 -fold of stream widths, following Montgomery and Buffington 1997) and for sampling of nutrient spiralling metrics at the reach scale (Baker and Webster 2017).

The two studied streams, namely Kalte Bode (N $\left.51^{\circ} 44^{\prime} 33^{\prime \prime}, \mathrm{E} 10^{\circ} 42^{\prime} 09^{\prime \prime}\right)$ and Selke (N 51 $41^{\prime} 11.5^{\prime \prime}$, $\left.\mathrm{E} 10^{\circ} 15^{\prime} 34^{\prime \prime}\right)$, are located in the Bode catchment (Harz Mountains, central Germany), which is part of the Terrestrial Environmental Observatories, a long-term monitoring program (Wollschläger and others 2017). At the study site, the Kalte Bode drains a catchment area of $26 \mathrm{~km}^{2}$. Its long-term mean discharge (MQ) and baseflow estimated from the long-term mean lowest discharge (MNQ) is $720 \mathrm{~L} \mathrm{~s}^{-1}$ and $180 \mathrm{~L} \mathrm{~s}^{-1}$, respectively (data from 1951 to 2014 provided by the Flood Prediction Centre of the state Saxony-Anhalt). The Selke study site drains a larger catchment area of $184 \mathrm{~km}^{2}$, with long-term MQ and MNQ of $1520 \mathrm{~L} \mathrm{~s}^{-1}$ and $240 \mathrm{~L} \mathrm{~s}^{-1}$, respectively (data from 1921 to 2015). The Kalte Bode catchment is mainly composed of forested $(58 \%)$, peatbog $(23 \%)$ and urban areas $(14 \%)$ and the Selke catchment is covered by forested $(70 \%)$ and arable areas (19\%) (EEA 2018). The riparian vegetation at the Kalte Bode reach is fragmented and composed of coniferous trees (mainly Picea albis) on the right bank and deciduous bushes and trees (mainly Alnus glutinosa) on the left bank. The Selke reach has well-developed riparian vegetation of deciduous trees, mainly alder (Alnus glutinosa).

\section{Field Methods}

We conducted two tracer injection experiments in each stream, one in summer 2014 and another in spring 2015 (Table 1). During each injection experiment, we measured $\mathrm{N}$ uptake and standing stocks at three spatial scales: micro, meso and reach scale. Six primary uptake compartments were sampled, including epilithic biofilms, thallophytes (mixture of filamentous autotrophs and bryophytes mainly Fontinalis sp.), submerged roots of alder trees, coarse benthic organic matter, such as leaves and wood, and shallow fine benthic organic matter
(FBOM). The mesoscale comprises the hydromorphologic habitats riffle and pool, which were visually distinguished by water-level slopes. The reach scale comprises a stream-specific riffle-pool sequence. Primary uptake compartments were sampled among three to five riffles and pools in the two stream reaches.

Tracer injection experiments were performed following Mulholland and others (2000), Ashkena and others (2004) and von Schiller and others (2009). We used ${ }^{15} \mathrm{~N}$-labelled ammonium $\left({ }^{15} \mathrm{~N}-\right.$ $\mathrm{NH}_{4}{ }^{+}$) as reactive tracer for two reasons: (1) We were interested in rapid $\mathrm{N}$ assimilation and quick ${ }^{15} \mathrm{~N}$ labelling of primary uptake compartments, and $\mathrm{NH}_{4}{ }^{+}-\mathrm{N}$ is commonly preferred over $\mathrm{NO}_{3}{ }^{-}-\mathrm{N}$ to meet biotic $\mathrm{N}$ demand due to the lower energy cost to assimilate the former $\mathrm{N}$ species (Naldi and Wheeler 2002; Hildebrand 2005). (2) Our focus was on assimilatory $\mathrm{N}$ uptake, and it is known that in-stream $\mathrm{NH}_{4}{ }^{+}-\mathrm{N}$ uptake is dominated by assimilatory processes (Peterson and others 2001; Tank and others 2018). Nonetheless, we expect that the trends observed for $\mathrm{NH}_{4}{ }^{+}-\mathrm{N}$ will hold for $\mathrm{NO}_{3}{ }^{-}-\mathrm{N}$, because assimilatory uptake of both $\mathrm{N}$ species is widely controlled by metabolic activity (Hall and others 2009; Tank and others 2018).

A solution containing the reactive tracer ammonium chloride (99\% enriched $\left.{ }^{15} \mathrm{NH}_{4} \mathrm{Cl}\right)$ in conjunction with the conservative tracer sodium bromide $(\mathrm{NaBr})$ was injected with a peristaltic pump (Watson Marlow, Falmouth, United Kingdom) at a distance of $250 \mathrm{~m}$ (Kalte Bode) and 140$170 \mathrm{~m}$ (Selke) upstream from the study reach to ensure complete mixing. The pump flow rate was set to achieve a target $\delta^{15} \mathrm{~N}$ enrichment in the stream water of $1000 \%$ in both streams and a target $\mathrm{Br}^{-}$concentration of $0.2 \mathrm{mg} \mathrm{L}^{-1}$ in Kalte Bode and $0.5 \mathrm{mg} \mathrm{L}^{-1}$ in Selke. The overall increase in instream $\mathrm{NH}_{4}{ }^{+}-\mathrm{N}$ concentration during the injection experiment was below $0.5 \%$ of the ambient level and thus did not change the natural $\mathrm{NH}_{4}{ }^{+}-\mathrm{N}$ pathway and precluded saturation effects (Mulholland and others 2002). We collected water samples manually and by autosamplers (AWS 2002, Endress + Hauser AG Reinach, Switzerland) at the beginning and end of the reaches during each ${ }^{15} \mathrm{~N}$ injection experiment to ensure that the stream reach was well mixed and to guarantee sampling of primary uptake compartments at plateau. All four ${ }^{15} \mathrm{~N}$ injection experiments lasted $24 \mathrm{~h}$ to assure significant enrichment of primary uptake compartments (Tank and others 2018). Plateau was reached after maximum $2 \mathrm{~h}$, and between $19 \mathrm{~h}$ and $24 \mathrm{~h}$ after start of the tracer injection we sampled primary uptake compartments and stream water. 


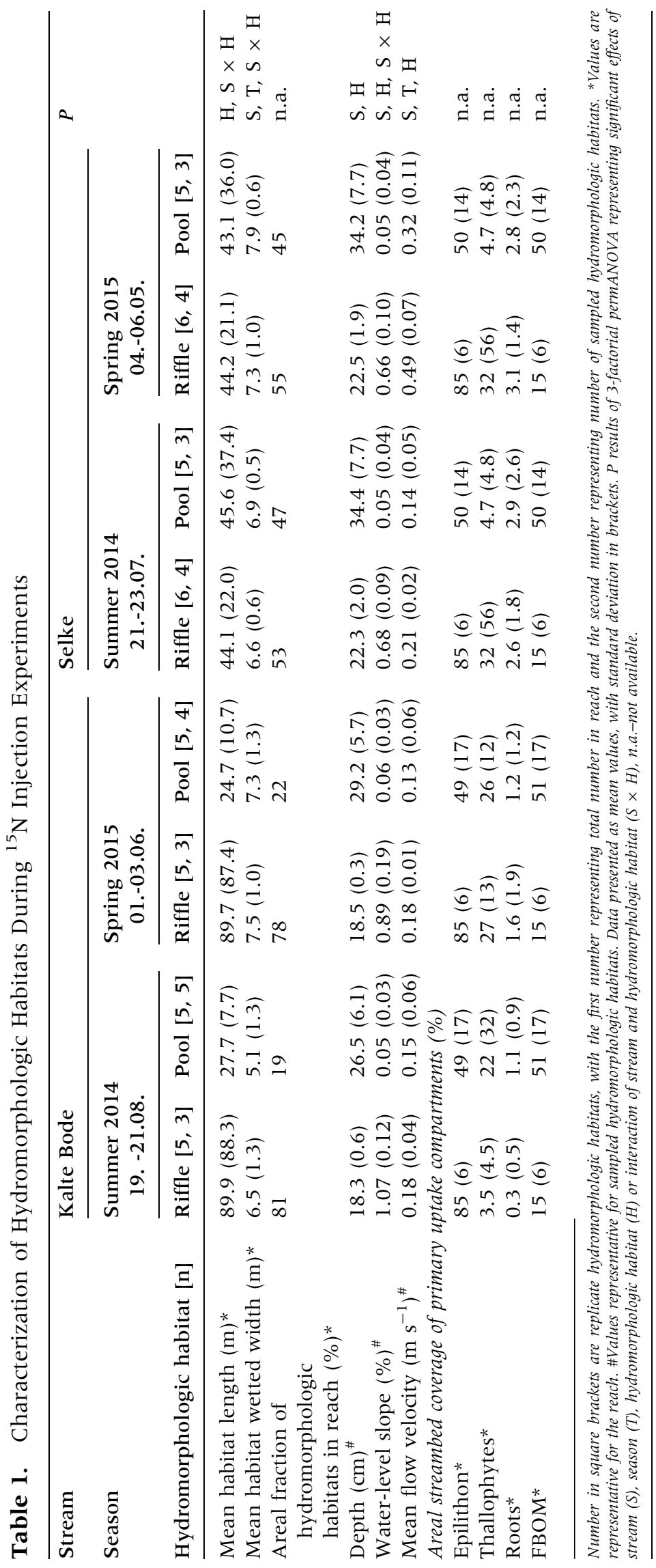


We sampled parameters necessary to calculate $\mathrm{N}$ uptake metrics at all hydromorphologic habitats, whereas parameters needed to characterize water chemistry were sampled at three sites only. Water samples for measuring the isotopic signature of ${ }^{15} \mathrm{~N}-\mathrm{NH}_{4}{ }^{+}$and ${ }^{15} \mathrm{~N}-\mathrm{NO}_{3}{ }^{-}$, and concentrations of $\mathrm{NH}_{4}{ }^{+}-\mathrm{N}, \quad \mathrm{NO}_{3}{ }^{-}-\mathrm{N}$ and $\mathrm{Br}^{-}$were collected in duplicate in each hydromorphologic habitat one day prior to tracer injection for background characterization and during plateau stage. At the beginning, mid and end of each reach the stream water was additionally sampled for dissolved organic carbon (DOC), soluble reactive phosphorus (SRP), chlorophyll $a$ (Chl $a$ ) and suspended particulate organic matter (SPOM). Water samples were immediately filtered through $0.2 \mu \mathrm{m}$ (prewashed cellulose acetate membrane, Sartorius) for ${ }^{15} \mathrm{~N}-\mathrm{NH}_{4}{ }^{+},{ }^{15} \mathrm{~N}-\mathrm{NO}_{3}{ }^{-}, \mathrm{NH}_{4}{ }^{+}-\mathrm{N}, \mathrm{NO}_{3}{ }^{-}-\mathrm{N}$, SRP and $\mathrm{Br}^{-}$. DOC was analysed in water samples filtered through $0.45 \mu \mathrm{m}$ (pre-washed cellulose acetate membrane, Sartorius). SPOM (filters pre-weight) and Chl $a$ suspended in water were collected on pre-ashed glass fibre filters (GFF, Sartorius). Samples were stored at $4^{\circ} \mathrm{C}$ or $-20^{\circ} \mathrm{C}\left({ }^{15} \mathrm{~N}^{-\mathrm{NH}_{4}}{ }^{+}, \mathrm{Chl} a\right.$, $\mathrm{SPOM}$ ) until further analyses. Water temperature, oxygen concentrations, $\mathrm{pH}$, conductivity were measured by an EXO2 multiparameter probe (YSI Incorporated, Yellow Springs, OH, USA) located at the beginning of the reach during the injections. Five light loggers (HOBO Pendant light and temperature logger, Onset Computer Corporation, Bourne, MA, USA) were deployed along the stream reach at $1.0-2.5 \mathrm{~m}$ height to measure light intensity every $15 \mathrm{~min}$, which was converted to photosynthetic active radiation (PAR, see also Risse-Buhl and others 2017) to calculate daily PAR $\left(\mathrm{mol} \mathrm{m}^{-2}\right.$ day $^{-1}$ ). The mean leaf area index of the reach (LAI, in \%), as measure of canopy coverage was estimated from a skyward image taken at each hydromorphologic habitat with a reflex camera (EOS 60D, Canon). Images were binarized, and the area of dark pixels was quantified using imaging software (Image J version 2.0.0).

Primary uptake compartments were sampled in duplicate from a riffle, and a pool located within the study reach one day prior to the injection experiment for their background ${ }^{15} \mathrm{~N}$. At plateau, primary uptake compartments were sampled in duplicate from each hydromorphologic habitat within the study reach. The next day, we collected samples to quantify standing stocks of each primary uptake compartment in the reach following a stratified random sampling (Mulholland and others 2000). Epilithic biofilms, thallophytes, roots and FBOM were sampled at sites of $100 \%$ coverage.
The coverage of epilithic biofilms and FBOM were estimated from underwater images (Lumix DMCFT3, Panasonic) taken at up to 15 locations in each hydromorphologic habitat. The streambed area covered by thallophytes and roots was estimated in the field at each injection experiment. Streambed area covered by primary uptake compartments was then multiplied by $\mathrm{N}$ in biomass to get the compartment-specific $\mathrm{N}$ standing stock at mesoscale and reach scale.

Epilithic biofilms were sampled by scrubbing and washing (using $0.2 \mu \mathrm{m}$ filtered stream water) a defined area of the illuminated side of three stones per hydromorphologic habitat. The defined area was projected to tin foil. The tin foil area was then quantified using imaging software (ImageJ version 2.0.0). We used an open-ended PVC cylinder pushed into the sediment to sample thallophytes, alder roots, leaves, wood (sampled area $0.11 \mathrm{~m}^{2}$ ) and FBOM (sampled area $0.02 \mathrm{~m}^{2}$ ) within a defined area. Only active submerged roots typically located at the stream-riparian edge were collected. After sampling, all samples were stored at $-20^{\circ} \mathrm{C}$ until further analyses.

\section{Laboratory Analyses}

The alkaline headspace diffusion procedure was

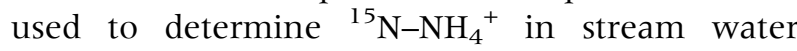
(Holmes and others 1998). In short, a 200-350-mL sample was made alkaline ( $\mathrm{pH} \mathrm{8-9)}$ in order to volatilize the $\mathrm{NH}_{4}^{+}$into the headspace, which is then absorbed onto an acidified filter (pre-ashed GFF, $2 \mathrm{M} \mathrm{KHSO}_{4}$ ) as ammonium sulphate. The filters were dried, loaded into a tin boat, combusted and isotope mass was measured on a Finnigan Delta S mass spectrometer (Thermo Scientific, Bremen, Germany). Duplicate samples were pooled to increase the mole mass, since $\mathrm{NH}_{4}{ }^{+}-\mathrm{N}$ concentration was at the lower limit of the procedure. ${ }^{15} \mathrm{~N}_{-} \mathrm{NO}_{3}{ }^{-}$was measured following the protocol of Wells and others (2016). In short, $\mathrm{NO}_{3}{ }^{-}-\mathrm{N}$ was converted into $\mathrm{N}_{2} \mathrm{O}$ using the denitrifier method (McIlvin and Casciotti 2011) and measured on a DeltaPlus isotope ratio mass spectrometer fitted with a gas bench (Thermo Scientific, Bremen, Germany). Standard deviation of duplicate measurements was $0.4 \%$. Concentration of the conservative tracer $\left(\mathrm{Br}^{-}\right)$was measured in untreated samples by inductively coupled plasma mass spectrometry (ICP-MS Triple Quadrupole, Agilent Technologies, Santa Clara, CA, USA). Standard deviation of duplicate measurements was lower than $5 \%$. Concentration of $\mathrm{NH}_{4}{ }^{+}-\mathrm{N}$ (DIN EN ISO 11732-E23 2005), $\mathrm{NO}_{3}{ }^{-}-\mathrm{N}$ (DIN EN ISO $13395-$ 
D28 1996), SRP (DIN EN ISO 15681 Part 2-D46 2005), DOC and Chl $a$ in water samples were analysed as described in Risse-Buhl and others (2017).

Samples of all primary uptake compartments were dried at $60^{\circ} \mathrm{C}$ for $48 \mathrm{~h}$ and ground to fine powder (Bead Ruptor 24, Omni International, Kannesaw, GA, USA). For larger wood fragments, the outer layer (few $\mathrm{mm}$ ) was removed and analysed for its isotopic signal. A subsample was weighed to the nearest $0.01 \mathrm{mg}$ (XA105DU, Mettler-Toledo, Gießen, Germany) and encapsulated in tins. For SPOM, a disc ( $1 \mathrm{~cm}$ in diameter) was cut from the whole filter and encapsulated in tins. The isotopic signal and $\mathrm{N}$ content of tin-encapsulated samples was measured with a Flash 2000 HT elemental analyser coupled via a ConFlo IV interfaced to a Delta V Advantage isotope ratio mass spectrometer (all Thermo Scientific, Bremen, Germany).

For each standing stock sample, dry mass (DM) and ash-free dry mass (AFDM) were measured after drying for $48 \mathrm{~h}$ at $60^{\circ} \mathrm{C}$ and combusting for 4 $\mathrm{h}$ at $500^{\circ} \mathrm{C}$, respectively. Sample DM was converted to $\mathrm{N}$ biomass by the proportion of mass present as $\mathrm{N}$ revealed from the mass spectrometer. Samples were weighed to the nearest $0.1 \mathrm{mg}$ (M-pact AX224, Sartorius). Chl $a$ of epilithic biofilms and FBOM was extracted in cool $90 \%$ ethanol for $24 \mathrm{~h}$ and measured spectrophotometrically (Cary60 UVvis, Agilent Technologies, Santa Clara, CA, USA) at $665 \mathrm{~nm}$. The autotrophic index was calculated as the ratio of Chl $a$ to AFDM as an indicator of shifts from autotrophic to heterotrophic dominance (Steinman and others 2017).

\section{Parameter Calculations}

The lengths and mean widths of the hydromorphologic habitats were determined with a tape measure. The vertical water-level difference between the up- and downstream end of a hydromorphologic habitat was measured with a level instrument (Ni 020 A, VEB Carl Zeiss Jena, Germany) and used to estimate the mean water-level slope. To determine mean water depth of each hydromorphologic habitat at Kalte Bode, we conducted a topographical survey deploying an electronic tachymeter with a differential GPS antenna and GNSS rover (Trimble GPS R8) when mean daily discharge was $570 \pm 70 \mathrm{~L} \mathrm{~s}^{-1}$ (mean \pm standard deviation). For Selke, mean water depth was estimated from topographical data provided by the local water authority and measured at a mean daily discharge of $260 \pm 80 \mathrm{~L} \mathrm{~s}^{-1}$. Discharge during the topographical surveys and tracer injection experiments were within a range of one to three times the baseflow and well below MQ. Moreover, the width to depth ratio in the stream reaches is high so that the increase in water depth due to higher discharge is small, and we thus assume comparable water depths at the topographical survey and injection experiments. Mean flow velocity of each hydromorphologic habitat was then estimated by dividing discharge by the cross-sectional area, which is the product of mean width and depth.

Nitrogen uptake was estimated (1) from compartment-specific ${ }^{15} \mathrm{~N}$ enrichment corrected for dilution and weighed to micro-, meso- and reachscale $\mathrm{N}$ biomass using percent coverage and (2) from longitudinal, reach-scale declines of ${ }^{15} \mathrm{~N}-\mathrm{NH}_{4}{ }^{+}$ in the water column based on LINXII protocols (Mulholland and others 2000).

Compartment-specific $\mathrm{N}$ uptake at microscale (microscale $\mathrm{U}_{\mathrm{PUC}}, \mathrm{mg} \mathrm{N} \mathrm{m}^{-2}$ day $^{-1}$ ) was calculated with the equation

$$
\begin{aligned}
& \text { Micro - scale UPUC } \\
& =\frac{\text { Micro }- \text { scale } \mathrm{N}_{\text {PUC }} \times\left(\text { MF }_{\text {PUC.P }}-\text { MFPUC.B }\right)}{\left(\frac{\text { Tracerflux }}{\mathrm{N}-\mathrm{NH}_{4}^{+} \text {flux }}\right) \times \mathrm{t}}
\end{aligned}
$$

where microscale $\mathrm{N}_{\mathrm{PUC}}$ is $\mathrm{N}$ in biomass of each primary uptake compartment, $\mathrm{MF}_{\mathrm{PUC} . \mathrm{B}}$ and $\mathrm{MF}_{\mathrm{PUC} . P}$ is mole fraction of each compartment during background and plateau, and $\mathrm{t}$ is time (1 day). Tracer flux ( $\mu \mathrm{g}^{15} \mathrm{~N} \mathrm{~s}^{-1}$ ) was calculated as product of the background-corrected mole fraction of ${ }^{15} \mathrm{~N}-\mathrm{NH}_{4}{ }^{+}$in the stream water, the $\mathrm{NH}_{4}{ }^{+-}-\mathrm{N}$ concentration $(\mathrm{C})$ and discharge $(\mathrm{Q})$ as follows

$$
\text { Tracer flux }=\frac{\left(\mathrm{MF}_{\mathrm{P}} \times \mathrm{C} \times \mathrm{Q}\right)}{\left(\mathrm{MF}_{\mathrm{B}} \times \mathrm{C} \times \mathrm{Q}\right)}
$$

where $M_{\mathrm{B}}$ and $\mathrm{MF}_{\mathrm{P}}$ are the mole fractions in stream water during background and plateau, respectively. For upscaling, N uptake was calculated with mesoscale $\mathrm{N}$ biomass by considering areal streambed coverage of primary uptake compartments in hydromorphologic habitats, and with reach-scale $\mathrm{N}$ biomass by considering the relative contribution of each hydromorphologic habitat to the reach. Values of single primary uptake compartments at mesoscale or reach scale were summed to calculate mesoscale $\mathrm{N}$ biomass and $\mathrm{N}$ uptake of riffles and pools or reach-scale $\mathrm{N}$ biomass and $\mathrm{N}$ uptake, respectively. To better illustrate differences between hydromorphologic habitats, mesoscale 
data were normalized by the maximum value of each injection experiment.

Injection of ${ }^{15} \mathrm{~N}-\mathrm{NH}_{4}{ }^{+}$increased $\delta^{15} \mathrm{~N}$ values of primary uptake compartments over an order of magnitude during all injections (Figure S1 for epilithic biofilms), but ${ }^{15} \mathrm{~N}-\mathrm{NH}_{4}{ }^{+}$flux declined significantly only along the Kalte Bode reach (during both seasons), while failing to decline along the Selke reach during either season (Figure S1). Therefore, ${ }^{15} \mathrm{~N}-\mathrm{NH}_{4}{ }^{+}$flux data were used to estimate reachscale nutrient spiralling metrics for Kalte Bode, but not for Selke. The decline of the natural logarithm of ${ }^{15} \mathrm{~N}-\mathrm{NH}_{4}{ }^{+}$flux downstream from the injection point revealed the reach-scale fractional uptake rate per unit distance $\left(\mathrm{k}_{\mathrm{W}}, \mathrm{m}^{-1}\right)$ and uptake length $\left(\mathrm{S}_{\mathrm{W}}=1 /\right.$ $\mathrm{k}_{\mathrm{W}}$, in $\left.\mathrm{m}\right)$ of $\mathrm{NH}_{4}{ }^{+}-\mathrm{N}$. Uptake velocity $\left(\mathrm{V}_{\mathrm{f}}, \mathrm{mm} \mathrm{min}^{-1}\right)$, which is an estimate of how quickly $\mathrm{N}$ is removed from the stream water into the primary uptake compartments, was calculated as $\mathrm{Q} \times \mathrm{W}^{-1} \times \mathrm{S}_{\mathrm{W}}^{-1} \times$ 60 , where $\mathrm{Q}$ is mean discharge $\left(\mathrm{L} \mathrm{s}^{-1}\right)$ and $\mathrm{W}$ is mean wetted width $(\mathrm{m})$. Whole-reach areal $\mathrm{N}$ uptake ( $\mathrm{U}_{\mathrm{WAT}}, \mathrm{mg} \mathrm{N} \mathrm{\textrm {m } ^ { 2 }}$ day $^{-1}$ ) was calculated by multiplying $\mathrm{V}_{\mathrm{f}}$ and mean $\mathrm{NH}_{4}{ }^{+}-\mathrm{N}$ concentration of all longitudinal samples in the study reach. The longitudinal profile of ${ }^{15} \mathrm{~N}-\mathrm{NO}_{3}{ }^{-}$was used to estimate the reach-scale fractional uptake rate per unit distance $\left(\mathrm{k}_{\mathrm{NIT}}, \mathrm{m}^{-1}\right)$ and nitrification rate $\left(\mathrm{U}_{\mathrm{NIT}}\right.$, $\mathrm{mg} \mathrm{N} \mathrm{m}{ }^{-2}$ day $^{-1}$; Microsoft Excel 2018 Solver tool) (von Schiller and others 2009).

\section{Statistics}

Graphical illustrations (ggplot2; Wickham 2009) and statistical tests were done using $\mathrm{R}$ software (3.5.0.; The R Core Team 2018). A factorial permutation analyses of variance (permANOVA, $\mathrm{R}$ package 'ImPerm'; Wheeler and Torchiano 2016) was used to test for the effects of compartments, hydromorphologic habitats, streams and seasons on compartment-specific $\mathrm{N}$ biomass and $\mathrm{N}$ uptake at micro, meso and reach scale. The permANOVA was further used to test for the effects of hydromorphologic habitats, streams and seasons on characteristics of hydromorphologic habitats as well as to test for effects of streams and seasons on dissolved nutrients. An analysis of covariance (ANCOVA, R package 'stats') was performed to compare the slopes of $\ln { }^{15} \mathrm{~N}$ tracer flux along the Kalte Bode reach between seasons.

\section{RESUltS}

\section{Microscale}

Epilithic biofilms, thallophytes, roots and leaves had on average $2.1 \% \mathrm{~N}$ per DM, whereas wood had
$1.3 \% \mathrm{~N}$ and FBOM had the lowest $\mathrm{N}$ content per DM with $0.5 \%$. The lowest C:N ratio was found in epilithic biofilms (mean 7.6) and thallophytes (mean 12.3). In comparison with epilithic biofilms and thallophytes, the mean $\mathrm{C}: \mathrm{N}$ ratio for roots (18.7), leaves (21.7), wood (34.2) and FBOM (18.9) was higher. The mean autotrophic index of epilithic biofilms ranged from 1.0 to 15.5, whereas that of FBOM was two orders of magnitude lower ranging from 0.04 to 0.9 , thus, indicating epilithic biofilms to be more autotrophic than FBOM.

Microscale $\mathrm{N}$ biomass of FBOM was significantly higher than that of all other primary uptake compartments across all streams and seasons ( 1 -factorial permANOVA: $\left.\mathrm{F}_{5}, \quad{ }_{159}=14.7, \quad P>0.001\right)$. Microscale $\mathrm{N}$ biomass of all primary uptake compartments was not significantly different between hydromorphologic habitats except that of wood (3factorial permANOVA: wood: $F_{1,}{ }_{21}=11.2$, $P=0.003$; all other compartments: $P>0.05$; Figure $2 \mathrm{~A}$ ). Wood had a higher microscale $\mathrm{N}$ biomass in pools than in riffles (Figure 2A). Microscale $\mathrm{N}$ biomass of some primary uptake compartments was significantly different between streams and seasons (3-fractorial permANOVA: $\mathrm{F}_{5}, 141=6.8$, $P<0.001)$. Epilithic biofilms had higher microscale $\mathrm{N}$ biomass in spring than in summer (1-fractorial permANOVA: $\mathrm{F}_{1}, 25=16.0, \quad P<0.001$ ). Similarly, thallophytes had higher microscale $\mathrm{N}$ biomass in Kalte Bode in spring than in summer and in Selke $\left(\mathrm{F}_{1,19}=4.5, P=0.05\right)$. Microscale $\mathrm{N}$ biomass of leaves was higher in summer than in spring $\left(\mathrm{F}_{1,24}=17.6, P<0.001\right)$.

The $\delta^{15} \mathrm{~N}$ enrichment of primary uptake compartments varied over three orders of magnitude. The highest $\delta^{15} \mathrm{~N}$ enrichment was observed in epilithic biofilms and thallophytes varying between $59 \%$ and $323 \%$ at both streams and seasons. The $\delta^{15} \mathrm{~N}$ signal decreased from roots $(25-38 \%$ o $)$ to leaves $(18-40 \%)$, wood $(9-14 \%)$ and FBOM $(-3$ to $7 \%$ ). Accordingly, microscale $\mathrm{N}$ uptake was significantly different among primary uptake compartments over all streams and seasons ( 1 -factorial permANOVA: $\left.\mathrm{F}_{5}, 157=4.1, P=0.002\right)$. Epilithic biofilms (mean (SD)) over all streams and seasons: 93.7 (129.4) $\mathrm{mg} \mathrm{N} \mathrm{m}^{-2}$ day $^{-1}$ ), thallophytes (58.5 (100.5) $\mathrm{mg} \mathrm{N} \mathrm{m}^{-2}$ day $^{-1}$ ) and roots (72.3 (99.2) mg $\mathrm{N} \mathrm{m}^{-2}$ day $^{-1}$ ) had higher microscale $\mathrm{N}$ uptake, compared with leaves (15.5 (28.2) $\mathrm{mg} \mathrm{N} \mathrm{m}^{-2} \mathrm{day}^{-1}$ ), wood (20.6 (30.4) $\mathrm{mg} \mathrm{N} \mathrm{m}^{-2}$ day $^{-1}$ ) and FBOM (34.6 (50.8) $\mathrm{mg} \mathrm{N} \mathrm{m}^{-2}$ day $^{-1}$ ). Therefore, we here consider epilithic biofilms, thallophytes and roots to be biologically more active than leaves, wood and FBOM. 
A
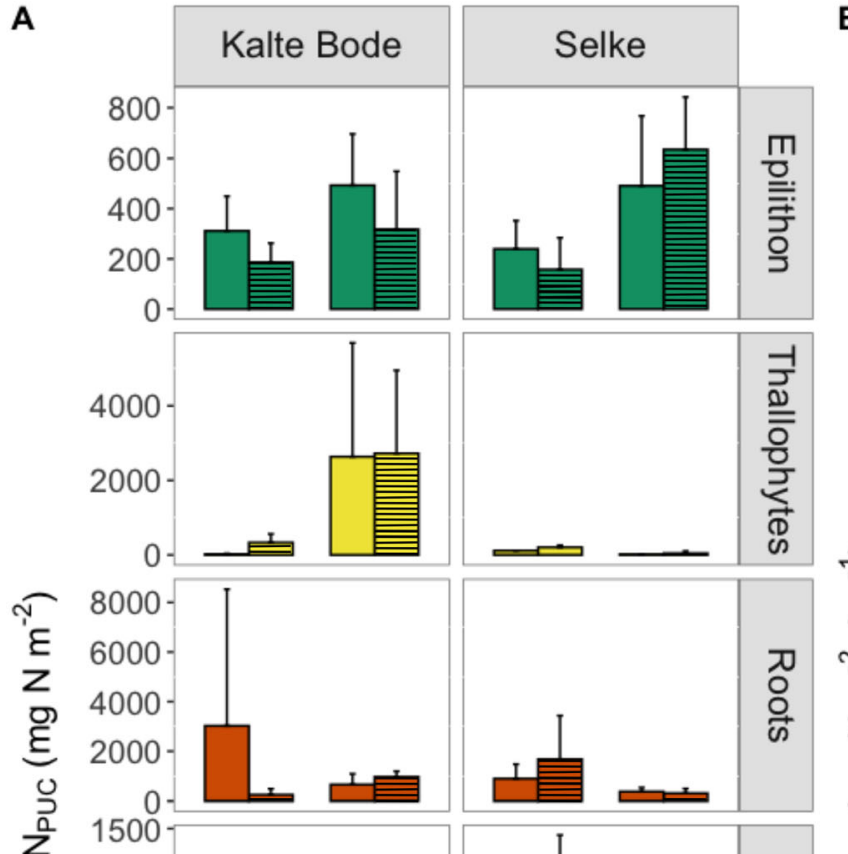

竞
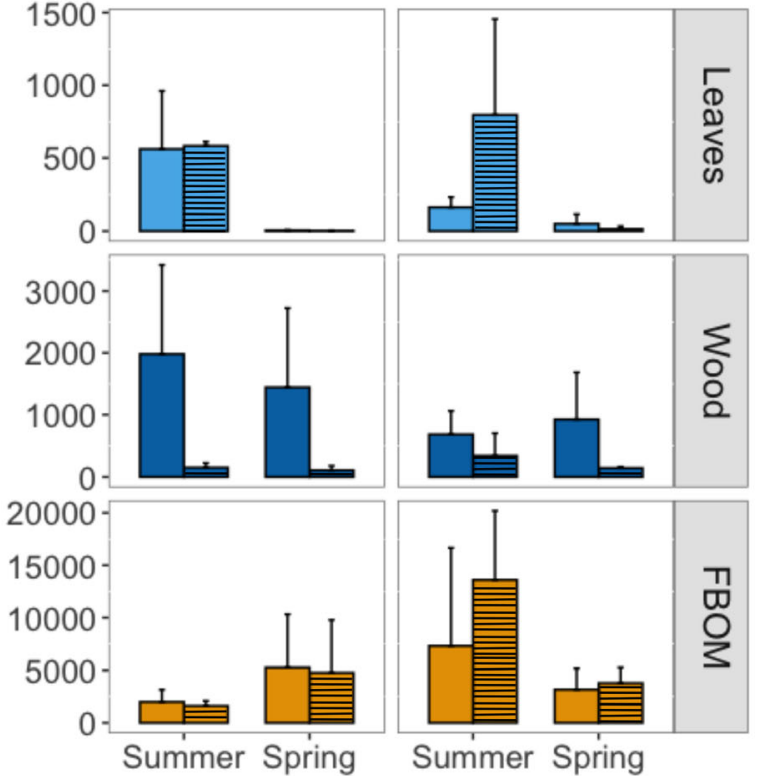

Summer Spring
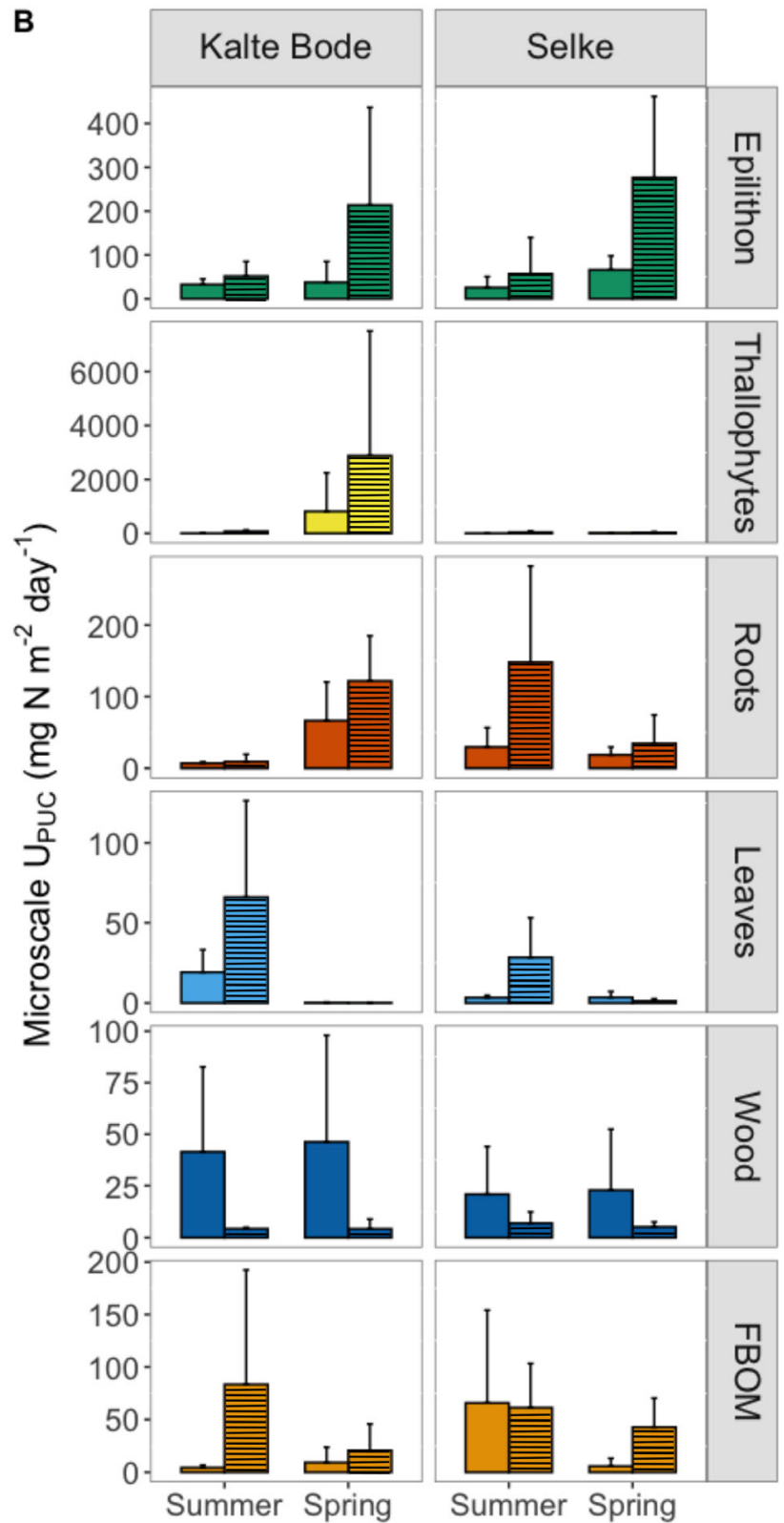

Figure 2. Microscale $\mathrm{N}$ biomass and $\mathrm{N}$ uptake of primary uptake compartments. A Microscale $\mathrm{N}$ biomass $\left(\mathrm{N}_{\mathrm{PUC}}, \mathrm{mg} \mathrm{N} \mathrm{m}^{-2}\right.$ ) and $\mathbf{B}$ microscale $\mathrm{N}$ uptake $\left(\mathrm{U}_{\mathrm{PUC}}, \mathrm{mg} \mathrm{N} \mathrm{m}^{-2}\right.$ ) in different hydromorphologic habitats of Kalte Bode and Selke during summer 2014 and spring 2015 (mean and positive standard deviation of hydromorphologic habitats, $n=3-5$ ). Open barspool, dashed bars-riffle. Please note different scales of y-axis for different primary uptake compartments.

Microscale $\mathrm{N}$ uptake of eplilithic biofilms was significantly different between hydromorphologic habitats, with higher microscale $\mathrm{N}$ uptake in riffles than in pools ( 3 -factorial permANOVA: $\mathrm{F}_{1,21}=7.5$, $P=0.012$; Figure 2B). A similar pattern was observed for microscale $\mathrm{N}$ uptake of leaves in summer (3-factorial permANOVA: hydromorphologic habitat $\times$ season $\left.\mathrm{F}_{1,20}=10.5, P=0.004\right)$. Microscale $\mathrm{N}$ uptake of thallophytes peaked in Kalte Bode spring 2015, and although microscale $\mathrm{N}$ uptake in riffles was higher than in pools, it was not significant $(P>0.05)$. In line with the effects of hydromorphologic habitats on $\mathrm{N}$ biomass, microscale $\mathrm{N}$ uptake of wood was higher in pools than in riffles $\left(\mathrm{F}_{1}\right.$ $\left.{ }_{21}=6.3, P=0.02\right)$. Microscale $\mathrm{N}$ uptake of all other primary uptake compartments tended to be higher in riffles than in pools, but this difference was not significantly $(P>0.05)$.

Stream-specific and seasonal trends of microscale $\mathrm{N}$ uptake of primary uptake compartments were 

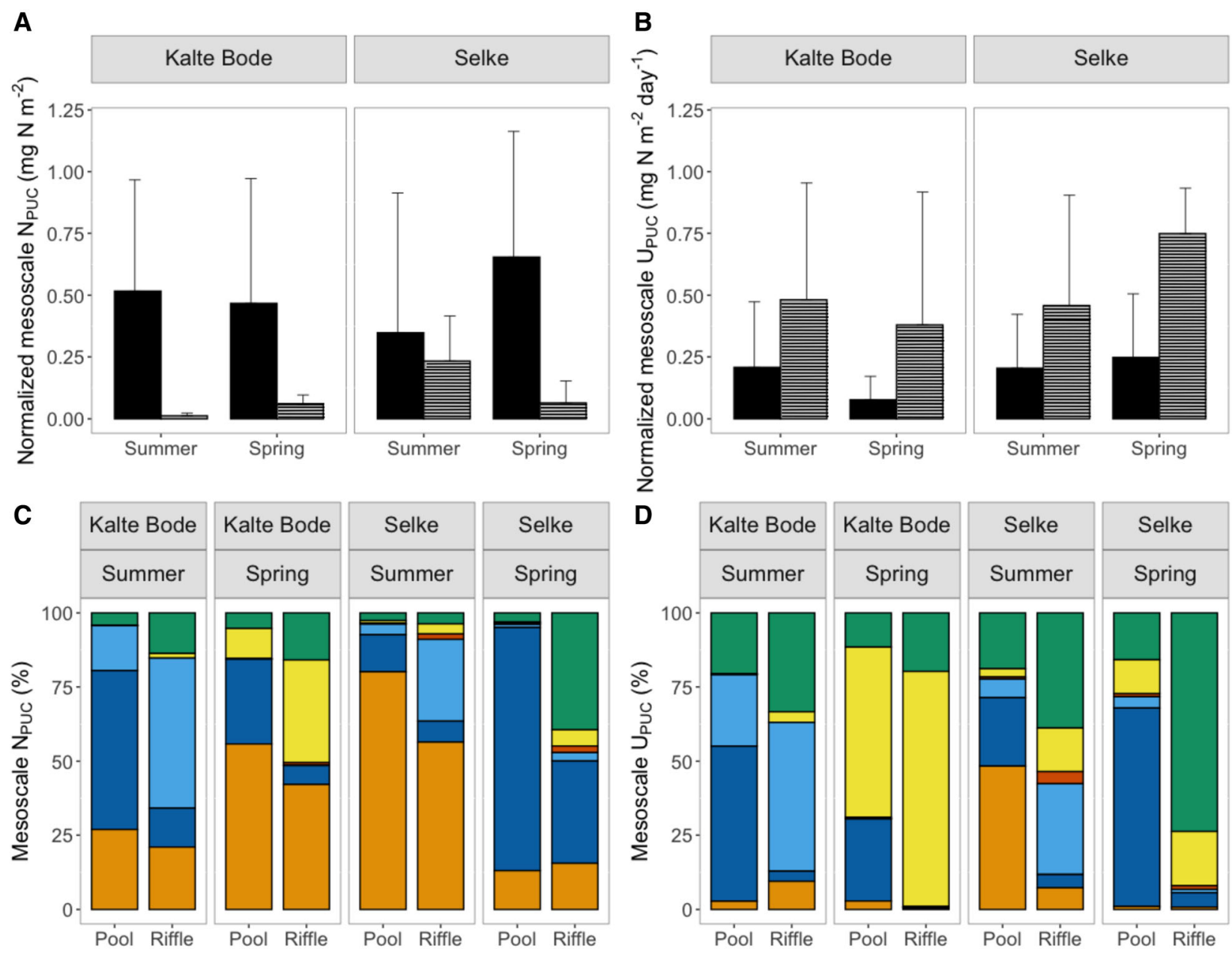

Figure 3. Mesoscale $\mathrm{N}$ biomass and $\mathrm{N}$ uptake. A Normalized mesoscale $\mathrm{N}$ biomass (mesoscale $\mathrm{N}_{\mathrm{PUC}}$ ), B normalized mesoscale $\mathrm{N}$ uptake (mesoscale $\mathrm{U}_{\mathrm{PUC}}$ ), C, D relative contribution of primary uptake compartments to mesoscale $\mathrm{N}$ biomass and $\mathrm{N}$ uptake, respectively, in the two different hydromorphologic habitats of each stream and season (mean and positive standard deviation of hydromorphologic habitats, $n=3-5$ ). Black bars-pool, grey and dashed bars-riffle; colour code of primary uptake compartments as Figure 2.

comparable to trends of microscale $\mathrm{N}$ biomass, except for FBOM (Figure 2B). Microscale N uptake of some primary uptake compartments was significantly different between seasons (3-fractorial permANOVA: interaction compartment $\times$ season: $\left.\mathrm{F}_{5,139}=3.6, P=0.004\right)$, but not between streams (interaction compartment $\times$ stream: $F_{5}, 139=1.2$, $P=0.32$ ). Epilithic biofilms had significantly higher microscale $\mathrm{N}$ uptake in spring compared to summer in both streams ( 1 -fractorial permANOVA: $\mathrm{F}_{1,25}=5.8, P=0.02$ ). In contrast, leaves showed higher microscale $\mathrm{N}$ uptake in summer than in spring $\left(\mathrm{F}_{1,25}=7.4, P=0.01\right)$. Despite the high microscale $\mathrm{N}$ biomass of FBOM and wood, their microscale $\mathrm{N}$ uptake was low. Microscale $\mathrm{N}$ uptake of FBOM was higher in summer than in spring in Selke, following the same trend as microscale $\mathrm{N}$ biomass. However, $\mathrm{N}$ biomass of FBOM was higher in spring in Kalte Bode where microscale N uptake was lowest.

\section{Mesoscale}

In both streams, riffles were significantly less deep and had a steeper water-level slope than pools (Table 1). Mean flow velocity of hydromorphologic habitats was 1.2-1.5 times higher in riffles compared to pools over both streams (Table 1). In addition, hydromorphologic habitats differed with respect to surface coverage of epilithic biofilms and FBOM (Table 1). A larger surface area of riffles was covered by epilithic biofilms compared to pools, whereas FBOM covered a larger surface area in pools. Surface coverage by thallophytes and roots did not differ between hydromorphologic habitats. 
Table 2. Physicochemistry of Stream Reaches During ${ }^{15} \mathrm{~N}$ Injection Experiments

\begin{tabular}{|c|c|c|c|c|c|}
\hline \multirow{2}{*}{$\begin{array}{l}\text { Stream } \\
\text { Season }\end{array}$} & \multicolumn{2}{|l|}{ Kalte Bode } & \multicolumn{2}{|l|}{ Selke } & \multirow[t]{2}{*}{$P$} \\
\hline & $\begin{array}{c}\text { Summer } 2014 \\
19 .-21.08 .\end{array}$ & $\begin{array}{c}\text { Spring } 2015 \\
01 .-03.06 .\end{array}$ & $\begin{array}{c}\text { Summer } 2014 \\
21 .-23.07 .\end{array}$ & $\begin{array}{c}\text { Spring } 2015 \\
04 .-06.05 .\end{array}$ & \\
\hline Daily Q $\left(\mathrm{L} \mathrm{s}^{-1}\right)$ & 220.8 & 260.6 & 306.7 & 771.8 & n.a. \\
\hline 3-week mean daily $\mathrm{Q}$ before injection $\left(\mathrm{L} \mathrm{s}^{-1}\right)$ & $483.0(236.8)$ & $332.5(57.5)$ & $550.7(340.4)$ & $1297.3(352.9)$ & n.a. \\
\hline Daily PAR (mol m${ }^{-2}$ day $\left.^{-1}\right)$ & $10.4(1.3)$ & $13.2(1.4)$ & $4.3(2.5)$ & $12.9(2.9)$ & n.s. \\
\hline LAI (\%) & $54.1(24.6)$ & $39.7(14.5)$ & $77.6(12.4)$ & $59.6(10.2)$ & $\mathrm{S}, \mathrm{T}$ \\
\hline Temperature $\left({ }^{\circ} \mathrm{C}\right)$ & $10.2(0.7)$ & $10.2(1.4)$ & $17.2(0.8)$ & $11.3(1.9)$ & n.a. \\
\hline Oxygen $\left(\mathrm{mg} \mathrm{L}^{-1}\right)$ & $10.6(0.2)$ & $10.7(0.4)$ & $8.7(0.3)$ & $10.5(0.8)$ & n.a. \\
\hline Conductivity $\left(\mu \mathrm{S} \mathrm{cm}^{-1}\right)$ & $89(2)$ & $92(2)$ & $496(11)$ & $365(15)$ & n.a. \\
\hline $\mathrm{pH}$ & $7.4(0.1)$ & $7.5(0.1)$ & $8.0(0.1)$ & $8.1(0.3)$ & n.a. \\
\hline $\mathrm{NH}_{4}{ }^{+}-\mathrm{N}\left(\mu \mathrm{g} \mathrm{L}^{-1}\right)$ & $10(0)$ & $68(14)$ & $45(5)$ & $57(4)$ & $\mathrm{S}, \mathrm{T}$ \\
\hline $\mathrm{NO}_{3}{ }^{-}-\mathrm{N}\left(\mu \mathrm{g} \mathrm{L}^{-1}\right)$ & $490(31)$ & $661(27)$ & $559(20)$ & $1170(32)$ & $\mathrm{S}, \mathrm{T}$ \\
\hline $\operatorname{SRP}\left(\mu g \mathrm{~L}^{-1}\right)$ & $3(0)$ & $3(0)$ & $47(1)$ & $11(1)$ & $\mathrm{S}, \mathrm{T}$ \\
\hline DIN: SRP (molar) & 75 & 110 & 6 & 50 & $S, T$ \\
\hline $\operatorname{DOC}\left(\mathrm{mg} \mathrm{L}^{-1}\right)$ & $3.5(0.2)$ & $2.8(0.3)$ & $2.8(0.3)$ & $3.2(0.4)$ & n.s. \\
\hline Chl $a\left(\mu \mathrm{g} \mathrm{L}^{-1}\right)$ & $0.3(0.01)$ & $0.6(0.2)$ & $0.5(0.02)$ & $2.6(0.2)$ & $\mathrm{S}, \mathrm{T}$ \\
\hline
\end{tabular}

$Q$ discharge, LAI leaf area index, SRP soluble reactive phosphorous, DIN dissolved inorganic nitrogen, DOC dissolved organic carbon, Chl a chlorophyll a. Data are presented as mean, with standard deviation in brackets. P results of 2-factorial permANOVA representing significant effects of stream (S) or season (T), n.s.-not significant, n.a.-not available.

Pools had a higher normalized mesoscale $\mathrm{N}$ biomass than riffles in both streams and seasons (3factorial permANOVA: $\mathrm{F}_{1,21}=8.5, P=0.008$; Figure $3 \mathrm{~A}$ ). Considering mesoscale $\mathrm{N}$ biomass of single primary uptake compartments, the significant interaction of hydromorphologic habitat and compartment $\left(\mathrm{F}_{5,126}=3.8, P=0.003\right)$ indicated that some primary uptake compartments were sorted by hydromorphology and others were not. In both streams and seasons, primary uptake compartments that were biologically more active, mainly epilithic biofilms and thallophytes, contributed more to mesoscale $\mathrm{N}$ biomass in riffles, whereas mesoscale $\mathrm{N}$ biomass in pools was dominated by primary uptake compartments that were biologically less active, mainly wood and FBOM (Figure $3 \mathrm{C}$ ). Leaves contributed more to riffle than to pool mesoscale $\mathrm{N}$ biomass in summer 2014.

Normalized mesoscale $\mathrm{N}$ uptake was 1.7-3.0 times higher in riffles than in pools $\left(\mathrm{F}_{1,21}=7.2\right.$, $P=0.014$; Figure 3B) despite lower normalized mesoscale $\mathrm{N}$ biomass in riffles. In both streams, epilithic biofilms and thallophytes contributed more to mesoscale $\mathrm{N}$ biomass in riffles than to that of pools irrespective of season (Figure 3D). The contribution of epilithic biofilms and thallophytes to mesoscale $\mathrm{N}$ uptake was higher in spring 2015 compared to summer 2014. As in riffles, mesoscale $\mathrm{N}$ uptake of Kalte Bode pools was dominated by thallophytes in spring 2015. In summer 2014, leaves contributed more to mesoscale $\mathrm{N}$ uptake in riffles, whereas wood and FBOM dominated mesoscale $\mathrm{N}$ uptake in pools.

\section{Reach Scale}

The two reaches differed in their mean water-level slope, which was twice as high in Kalte Bode $(0.83 \%)$ than in Selke $(0.39 \%)$. The streambed areal coverage of riffles and pools differed between the two stream reaches (Table 1). At Kalte Bode, riffles contributed $78 \%-81 \%$ and pools contributed $19 \%-22 \%$ to total reach area. The share of riffles $(53 \%-55 \%)$ and pools $(45 \%-47 \%)$ was more balanced at the Selke.

Discharge was comparable between streams in summer 2014, but was three times higher at the Selke than at the Kalte Bode in spring 2015 (Table 2). The latter experienced stable low discharge for a period of three weeks before the injection experiment. In both streams, daily PAR was highest and canopy coverage lowest in spring 2015 compared to summer 2014. Leaf area index was highest at Selke during summer 2014 over all tracer experiments. Both streams were well oxygenated and daily mean stream water temperature ranged from 10.2 to $17.2{ }^{\circ} \mathrm{C}$. Conductivity, $\mathrm{pH}$ and $\mathrm{Chl} a$ were lower at Kalte Bode than at Selke.

Across all streams and seasons, reach-mean $\mathrm{NH}_{4}{ }^{+}-\mathrm{N}$ concentration was one order of magnitude lower than $\mathrm{NO}_{3}{ }^{-}-\mathrm{N}$ concentration, but averaged $45 \mu \mathrm{g} \mathrm{L}^{-1}$ and ranged from 10 to $68 \mu \mathrm{g} \mathrm{L}^{-1}$ (Ta- 

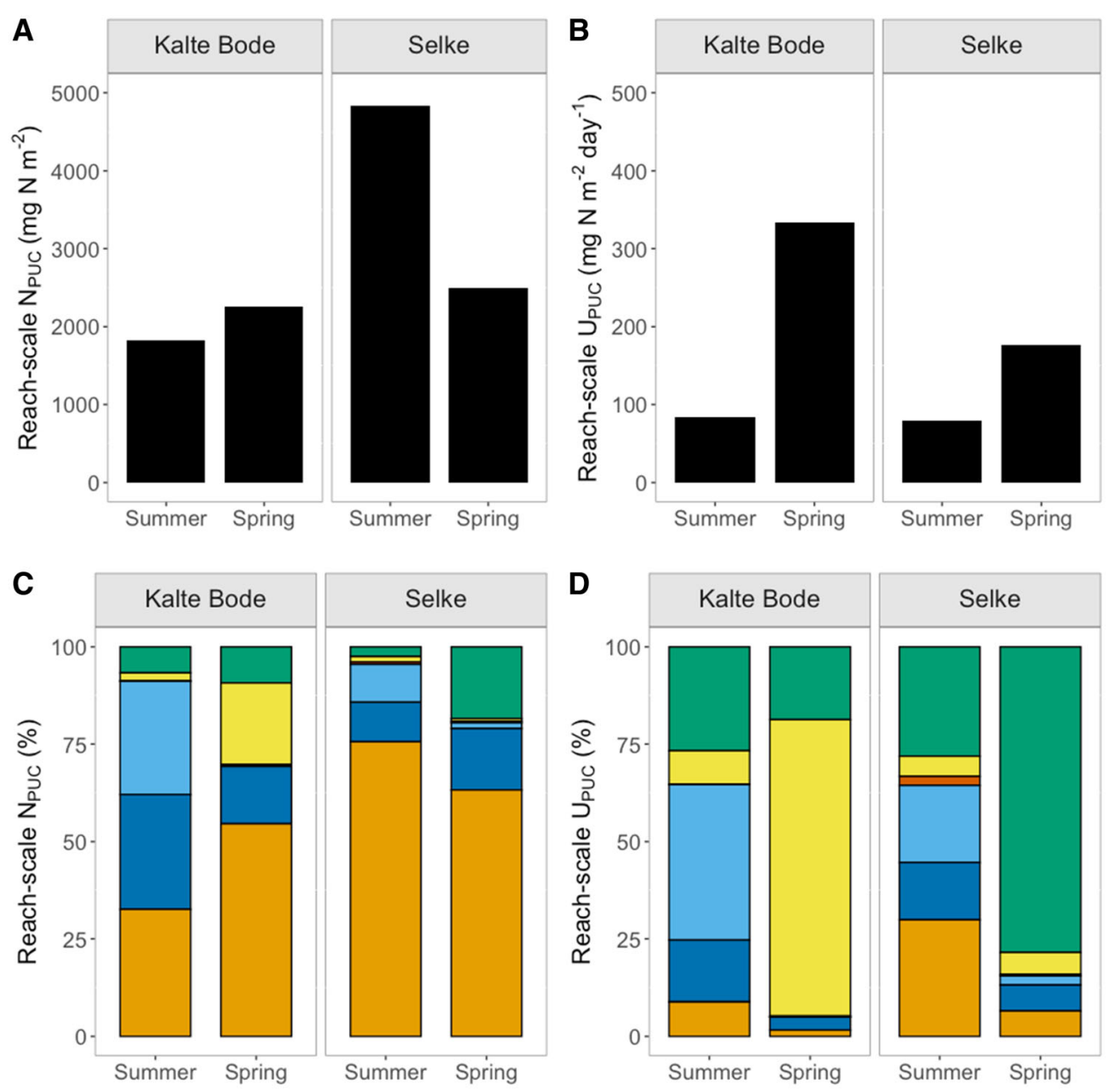

Figure 4. Reach-scale $\mathrm{N}$ biomass and $\mathrm{N}$ uptake. A Reach-scale $\mathrm{N}$ biomass (reach-scale $\mathrm{N}_{\mathrm{PuC}}$ ), B reach-scale $\mathrm{N}$ uptake (reach-scale $\mathrm{U}_{\mathrm{PUC}}$ ), C, D relative contribution of primary uptake compartments to reach-scale $\mathrm{N}$ biomass and $\mathrm{N}$ uptake, respectively, in Kalte Bode and Selke during summer 2014 and spring 2015. Colour code of primary uptake compartments as Figure 2.

ble 2). Seasonally, $\mathrm{NH}_{4}{ }^{+}-\mathrm{N}$ and $\mathrm{NO}_{3}{ }^{-}-\mathrm{N}$ concentrations were lower in summer 2014 than in spring 2015 at both streams and lowest at Kalte Bode in summer 2014. SRP concentration was one order of magnitude lower at Kalte Bode compared to Selke, resulting in a higher DIN:SRP ratio in the former. Accordingly, the Kalte Bode had less DIN available and together with lower SRP concentration than the Selke, creating an evident gradient in DIN:SRP.

Reach-scale standing stock of all primary uptake compartments ranged from 75.5 to $111.2 \mathrm{~g}$ AFDM $\mathrm{m}^{-2}$ and reach-scale $\mathrm{N}$ standing stock ranged from 1.8 to $4.8 \mathrm{~g} \mathrm{~N} \mathrm{~m}^{-2}$ (Figure $4 \mathrm{~A}$ ). In summer 2014, reach-scale $\mathrm{N}$ standing stock was 2.7 times higher in Selke than in Kalte Bode, whereas it was comparable between streams in spring 2015.

Reach-scale $\mathrm{N}$ biomass was dominated by FBOM, which made up between $32.6 \%$ and $75.6 \%$ of $\mathrm{N}$ stored over both streams and seasons (Figure 4C), although FBOM covered only 23-34\% of the streambed surface. Reach-scale N biomass of FBOM was 1.3-6.2 times higher in Selke than in Kalte Bode, but that of epilithon, leaves and wood was comparable between streams. Leaves had a higher share of reach-scale $\mathrm{N}$ biomass in summer 2014 than in spring 2015. Roots made up between 0.1 and $0.3 \%$ of reach-scale $\mathrm{N}$ biomass and covered less than $3 \%$ of the streambed surface. Thallophytes contributed more to reach-scale $\mathrm{N}$ biomass in Kalte Bode in spring $2015(21.0 \%)$ than in all other experiments in either stream. Accordingly, they covered $22 \%$ of the streambed surface in Kalte Bode in spring 2015, but covered between $8 \%$ and $11 \%$ of the streambed surface in all other experiments. Although, epilithic biofilms covered 66$77 \%$ of the streambed surface area in both streams, epilithic biofilms contributed less than $20 \%$ to 
reach-scale $\mathrm{N}$ biomass, with a larger share in spring 2015 compared to summer 2014.

Reach-scale $\mathrm{N}$ uptake ranged between 79.6 and $334.1 \mathrm{mg} \mathrm{N} \mathrm{m}^{-2}$ day $^{-1}$. Seasonal differences in reach-scale $\mathrm{N}$ uptake were comparable between streams, showing lowest rates in summer 2014 and rates one order of magnitude higher in spring 2015 (Figure 4B). The relative contribution of primary uptake compartments to reach-scale $\mathrm{N}$ uptake was comparable between streams but distinct for seasons (Figure 4D). Despite the low contribution to reach-scale $\mathrm{N}$ biomass, epilithic biofilms contributed $18.7-78.5 \%$ to reach-scale $\mathrm{N}$ uptake. Reach-scale $\mathrm{N}$ uptake in spring 2015 was mainly driven by thallophytes $76.0 \%$ in Kalte Bode and epilithic biofilms 78.5\% in Selke. In summer 2014, leaves contributed $19.7 \%$ and $39.9 \%$ and FBOM $8.8 \%$ and $29.9 \%$ to reach-scale $\mathrm{N}$ uptake at Kalte Bode and Selke, respectively. Roots contributed less than $2 \%$ to reach-scale $\mathrm{N}$ uptake in all experiments.

Fractional uptake rate per unit distance $\left(\mathrm{k}_{\mathrm{W}}\right)$ in Kalte Bode was significantly higher in summer 2014 than in spring $2015\left(\mathrm{~F}_{1}, \quad 21=122.0\right.$, $P<0.001$, Table S1). Similarly, $\mathrm{S}_{\mathrm{W}}$ was shorter and $V_{f}$ faster in summer $2014 \quad(513.4 \mathrm{~m}$ and $\left.4.0 \mathrm{~mm} \mathrm{~min}^{-1}\right)$ compared to spring $2015(678.9 \mathrm{~m}$ and $3.1 \mathrm{~mm} \mathrm{~min}^{-1}$ ). Areal $\mathrm{N}$ uptake (U $\mathrm{U}_{\mathrm{WAT}}$ ) was lowest in summer 2014 (57.2 $\mathrm{mg} \mathrm{N} \mathrm{m}^{-2}$ day $^{-1}$ ), which coincided with the lowest $\mathrm{NH}_{4}{ }^{+}-\mathrm{N}$ concentration (see Table 2). In spring 2015, areal $\mathrm{N}$ uptake peaked at $321.4 \mathrm{mg} \mathrm{N} \mathrm{m}^{-2}$ day $^{-1}$ and mirrored the trend observed for reach-scale $\mathrm{N}$ uptake (see Figure $4 \mathrm{~B})$. The values of nitrification $\left(\mathrm{U}_{\mathrm{NIT}}\right)$ were one order of magnitude higher in summer 2014 compared to spring 2015 and accounted for $32.3 \%$ and $1.6 \%$ of areal $\mathrm{N}$ uptake, respectively (Table $\mathrm{S} 1$ ). The concentration of SPOM ranged between $0.41 \mathrm{mg} \mathrm{L}^{-1}$ and $3.19 \mathrm{mg} \mathrm{L}^{-1}$ with lower values in Kalte Bode (Table S1). Calculations of SPOM uptake and flux indicate that only a small fraction of $\mathrm{U}_{\text {WAT }}$ was channelled by SPOM activity and that the export of ${ }^{15} \mathrm{~N}$ in the form of SPOM was negligible.

\section{DisCUSSION}

A better insight into the scaling mechanisms of $\mathrm{N}$ uptake and of the multiple feedbacks between pattern and process at different spatial scales is essential for thorough understanding of stream ecosystem functionings. Across-scale effects have been demonstrated for small-scale hydraulic heterogeneity shaping $\mathrm{N}$ uptake and carbon fluxes at reach scale (Singer and others 2010; Peipoch and others 2016; Hanrahan and others 2018) and for surface-subsurface exchange modulating stream water nutrient concentration (Dent and others 2001). In our study, we applied a novel scaling concept to better understand cross-scale impacts on in-stream assimilatory $\mathrm{N}$ uptake. We found a set of nested drivers influencing $\mathrm{N}$ uptake at different spatial scales that either emerged from smaller scales or were constrained by larger scales. We identified hydromorphology as the prominent factor affecting $\mathrm{N}$ uptake at the micro- and mesoscale, especially its role in (1) locally affecting microscale $\mathrm{N}$ uptake of primary uptake compartments, and (2) sorting of primary uptake compartments in hydromorphologic habitats at the mesoscale, which in turn affected mesoscale $\mathrm{N}$ uptake. The collective properties of primary uptake compartments at microscale, namely pronounced differences in compartment-specific $\mathrm{N}$ content, C:N, autotrophic index and $\mathrm{N}$ uptake, and hydromorphologic sorting both affected $\mathrm{N}$ uptake at the mesoscale. Furthermore, environmental constraints such as constant low discharge and good light availability promoted the establishment of additional primary uptake compartments, for example, thallophytes on top of epilithic biofilms that shaped $\mathrm{N}$ uptake at all spatial scales. We expect that the trends observed for ammonium will hold for other $\mathrm{N}$ species, because assimilatory uptake is widely controlled by metabolic activity (Hall and others 2009; Hanrahan and others 2018; Tank and others 2018). Nonetheless, this could be tested with forthcoming ${ }^{15} \mathrm{~N}$ tracer injection experiments using ${ }^{15} \mathrm{~N}-\mathrm{NO}_{3}{ }^{-}$. Similarly, the assimilatory uptake of dissolved organic $\mathrm{N}$ could be tested using $\mathrm{DO}^{15} \mathrm{~N}$ in future studies.

\section{Properties of Primary Uptake Compartments}

Primary uptake compartments in the studied stream reaches showed contrasting $\mathrm{N}$ content in $\mathrm{DM}, \mathrm{C}: \mathrm{N}$ ratio, autotrophic index, microscale $\mathrm{N}$ biomass, and microscale $\mathrm{N}$ uptake. Epilithic biofilms and thallophytes were autotroph-dominated with the lowest C:N ratio, whereas FBOM was heterotroph-dominated with the highest $\mathrm{C}: \mathrm{N}$ ratio. Microscale $\mathrm{N}$ uptake of epilithic biofilms, thallophytes and roots was higher than that of leaves, wood and FBOM. Therefore, we here consider epilithic biofilms, thallophytes and roots to be biologically active and leaves, wood and FBOM to be biologically less active.

Irrespective of spatial scale, epilithic biofilms and thallophytes were hot spots of nutrient uptake in both streams. Other studies have shown that 
FBOM can substantially contribute to $\mathrm{N}$ uptake, in addition to epilithic biofilms and thallophytes (Peipoch and others 2016; Ribot and others 2017). However, in open canopy streams or during spring, epilithic biofilms and thallophytes usually dominate $\mathrm{N}$ uptake with a lower contribution of FBOM (Kemp and Dodds 2002; Parker and others 2018; Tank and others 2018). Epilithic biofilms were dominated by autotrophs highlighting their role and that of thallophytes over heterotroph-dominated primary uptake compartments (FBOM) for $\mathrm{N}$ uptake in the studied stream reaches. Thus, the collective properties of primary uptake compartments at microscale, that is, their different community composition and biological activity, may generate the template for biological activity and biogeochemical consequences at larger spatial scales.

\section{Hydromorphology Impacts N Uptake at Microscale and Mesoscale}

At the microscale, local hydromorphologic conditions such as the interaction between hydraulics and bed morphology are expected to modulate $\mathrm{N}$ uptake of primary uptake compartments (Figure 1). Our results demonstrate that $\mathrm{N}$ uptake by different primary uptake compartments was in the majority of cases higher in riffles than in pools, both differing in hydromorphology. We here used mean depth, water-level slope and mean flow velocity (a ratio of discharge and wetted cross-sectional area) to distinguish hydromorphologic habitats. However, the high spatial variability of flow velocity and water depth results in small-scale heterogeneity of $\mathrm{N}$ uptake within hydromorphologic habitats (Peipoch and others 2016). The authors showed that although patches of increased $\mathrm{N}$ uptake occupy a small percentage of the total reach, they are generally located within riffle habitats. Riffles typically occur at sites with high hydraulic transport rates that are hot spots of biogeochemical activity (Larned and others 2004; Reidenbach and others 2010). Our study supports these findings illustrating that riffles with higher mean flow velocity and lower water depth accommodated biogeochemical hot spots of assimilatory $\mathrm{N}$ uptake.

\section{Hydromorphologic Sorting of Primary Uptake Compartments at Mesoscale}

Our data showed higher mesoscale $\mathrm{N}$ uptake in riffles than in pools. At this scale, we expected hydromorphology to additionally affect the sorting of primary uptake compartments (coverage and $\mathrm{N}$ biomass) further explaining patterns of mesoscale $\mathrm{N}$ uptake (see Figure 1). Our results confirmed this expectation and showed a higher contribution of biologically more active primary uptake compartments that were autotroph-dominated and had lower $\mathrm{C}: \mathrm{N}$ ratio such as epilithic biofilms and thallophytes to mesoscale $\mathrm{N}$ biomass and $\mathrm{N}$ uptake in riffles. In contrast, pools were dominated by biologically less active primary uptake compartments that were heterotroph-dominated and had higher $\mathrm{C}: \mathrm{N}$ ratio such as wood and FBOM. This hydromorphologic sorting of primary uptake compartments resulted in higher mesoscale $\mathrm{N}$ uptake in riffles than in pools, although the latter had significantly higher mesoscale $\mathrm{N}$ biomass. The higher $\mathrm{N}$ biomass in the studied pools was dominated by wood and FBOM that typically accumulate in this hydromorphologic habitat (Kobayashi and Kagaya 2008). Wood and FBOM have a high detrital N proportion and a low microbial $\mathrm{N}$ proportion (Sanzone and others 2001; Tank and others 2018); thus, their contribution to mesoscale $\mathrm{N}$ uptake is lower than for instance that of epilithon or thallophytes. Our results are in line with results from two New Zealand streams showing that $\mathrm{N}$ uptake of FBOM was higher in pools, whereas that of epilithic biofilms and thallophytes was higher in riffles (Simon and others 2004). Similarly, N uptake of epilithon was higher in riffles than in pools in a prairie stream (O'Brien and Dodds, 2008). Our study builds on previous research findings by pointing out the importance of hydromorphologic sorting of the coverage and $\mathrm{N}$ biomass of different primary uptake compartments on $\mathrm{N}$ uptake at mesoscale.

\section{Environmental Constraints-Shaped Patterns at Reach Scale}

We expected that geomorphology, that is, the contrasting configuration of hydromorphologic habitats of the two study reaches, would result in different reach-scale $\mathrm{N}$ uptake (see Figure 1). Our results confirmed this expectation in spring 2015 only. Geomorphologic features such as riffle-pool transitions or gravel-bar edges where surface-subsurface exchange occurs influence nutrient processing and retention across scales (Dent and others 2001). Here, we focused on the benthic zone and did not sample the hyporheic zone. Conservative tracer data of our injection experiments showed only weak connection between surface and hyporheic water (data not shown). Even when the connection between surface and hyporheic water is 
low, the hyporheic zone can disproportionately contribute to in-stream $\mathrm{N}$ uptake (Mendoza-Lera and others 2019). We therefore assume that besides the streambed area covered by the contrasting hydromorphologic habitats the contribution of surface-subsurface exchange sites may be crucial to shape $\mathrm{N}$ dynamics at reach scale.

In summer 2014, reach-scale $\mathrm{N}$ uptake was comparable between the two montane gravel-bed streams despite the contrasting configuration of hydromorphologic habitats in the two stream reaches. Geomorphology (channel morphology and streambed characteristics) and hydrology (discharge) are important in creating surface transient storage zones affecting hydraulic residence time and, thus, in-stream biogeochemical processes (Martí and Sabater 1996; Gücker and Boëchat 2004; Baker and others 2012; Patil and others 2013). On top of that, our data indicate the importance of hydromorphologic sorting. $\mathrm{N}$ biomass in Selke was 2.6 times higher than in Kalte Bode, presumably resulting in a comparable $\mathrm{N}$ uptake between the two stream reaches. We assume that hydromorphologic sorting of $\mathrm{N}$ biomass at reach scale superimposed the expected differences in $\mathrm{N}$ uptake between the two stream reaches. To verify this assumption, future research should focus on investigating the distribution patterns of primary uptake compartments and process rates at a larger ( $>2$ reaches) range of geomorphologic configuration.

In addition to hydromorphologic configuration of the reaches, a bloom of thallophytes occurred under a prolonged period of low discharge and high light conditions in the Kalte Bode. The bloom, which was mainly composed of colony-forming diatoms and cyanobacteria (Risse-Buhl and others 2020 ), covered $22 \%$ of the Kalte Bode reach and caused $\mathrm{N}$ uptake to peak. The high contribution of thallophytes to assimilatory $\mathrm{N}$ uptake is in line with previous studies (Mulholland and others 2000; Tank and others 2018), but reach-scale $\mathrm{N}$ uptake of thallophytes during the bloom in the studied streams was up to two orders of magnitude higher. During this period of reduced shear stress, filamentous communities that often protrude up into the stream water profit from the easy penetration of water currents into the mats (Larned and others 2004). The elongated growth is viewed as a strategy for maximizing nutrient acquisition by extending absorptive tissue into the turbulent flow (Biggs and others 1998b), which increases overall mass transfer to the plants (Biggs and others 1998a; Larned and others 2004). The low SRP concentration and high DIN:SRP ratio in the Kalte Bode during spring 2015 might have created limiting conditions for thallophyte growth. We speculate that the filamentous growth form of thallophytes might have been a consequence of low SRP concentration especially in relation to DIN concentration to maximize assimilatory $\mathrm{N}$ uptake. Large-scale environmental drivers thus opened a niche for an additional primary uptake compartments, the thallophytes, taking a dominant role in $\mathrm{N}$ uptake at micro, meso and reach scale.

Furthermore, compartment-specific $\mathrm{N}$ uptake at reach scale is in the range of published rates of $\mathrm{N}$ uptake of headwater, open-canopy streams of comparable discharge (Peterson and others 2001; Ribot and others 2017; Tank and others 2018). Our results show higher reach-scale assimilatory $\mathrm{N}$ uptake and lower nitrification (Kalte Bode) during spring 2015 compared to summer 2014. Spring is likely a biologically more active season because of higher light availability compared to the summer period (Table 1). Irradiation and canopy cover by riparian vegetation play a key role in microbially mediated $\mathrm{NH}_{4}{ }^{+}-\mathrm{N}$ assimilation (Tank and others 2018), regulating the balance between $\mathrm{NH}_{4}{ }^{+}$oxidation and assimilation (Lipschultz and others 1985; Merbt and others 2012) and retention of $\mathrm{NO}_{3}{ }^{-}$(Kunz and others 2017). As temperature was comparable between seasons in our study streams, light seemed to be an important driver of reachscale $\mathrm{N}$ uptake.

\section{Conclusions}

Our study highlights the set of controlling factors for $\mathrm{N}$ uptake nested over increasing spatial scales. We pointed out the important role of primary uptake compartment properties at microscale and of hydromorphologic sorting of primary uptake compartments at mesoscale shaping their streambed coverage and $\mathrm{N}$ biomass in hydromorphologic habitats and, hence, mesoscale $\mathrm{N}$ uptake. Furthermore, larger-scale constraints can superimpose lower-scale mechanisms of $\mathrm{N}$ uptake: for example, at mass developments of thallophytes probably supported by low flow and high light conditions. Overall, the mechanisms identified here, namely hydromorphology and hydromorphologic sorting, were essential to scale local microbial activity to the flux of matter in catchments and to predict $\mathrm{N}$ uptake under changing environmental conditions. Our hierarchical-scale approach might support decisions in stream restoration especially as we look to a more uncertain future. Here, ecological function, including $\mathrm{N}$ uptake, is increasingly recognized as important target for stream restoration (von 
Schiller and others 2008) to improve downstream water quality (Alexander and others 2007; Baker and others 2012). However, integrating functional parameter into management practices requires knowledge on the effect of local measures at microscale on larger-scale processes and on the mechanisms controlling those processes. Here, we demonstrate that hydromophologic sorting and the selection of primary uptake compartments differing in their biologic activity at the mesoscale is such an important mechanism.

\section{ACKNOWLEDGEMENTS}

We are grateful to $\mathrm{P}$. Portius and his team for technical support as well as S. Bauth, B. Bayer, B. Boehrer, M. Brauns, M. Diener, S. Geisthard, H. Goreczka, S. Halbedel, M. Herzog, A. Hoff, C. Hoffmeister, K. Kalla, N. Kamjunke, K. Kirschner, U. Kiwel, B. Kuehn, U. Kuhlicke, V. Kunz, K. Lerche, U. Link, I. Locker, C. Mendoza-Lera, H. Norf, N. Oberhoffner, L. Parlow, K. Rahn, C. Seiler, I. Siebert, U. Strachauer, C. Voelkner, N. Wells, K. Westphal, M. Wieprecht and R. Wild for their invaluable help with sampling, sample preparation and sample analyses. J. Zubrodt, K. Knoeller and R. M. Michener analysed samples for stable isotopes of nitrogen species. A. Musolff provided data on land use in catchments. We are thankful to three anonymous reviewers whose valuable comments strongly improved this manuscript. The research profited from the TERENO (Terrestrial Environmental Observatories) infrastructure.

\section{FUNDING}

Open Access funding enabled and organized by Projekt DEAL. The project was financed by research grants from the German Research Foundation (WE 3545/6-1 and LO 1150/8-1). U.R.-B. was additionally supported by a grant from the German Research Foundation (RI 2093/2-1). D.v.S. was a Serra Húnter Fellow and was additionally supported by the research group grant FORESTREAM from the Catalan Government (2017 SGR 976).

\section{Compliance with ethical standards}

Conflict of interest The authors declare that they have no conflict of interest.

\section{OPEN ACCESS}

This article is licensed under a Creative Commons Attribution 4.0 International License, which per- mits use, sharing, adaptation, distribution and reproduction in any medium or format, as long as you give appropriate credit to the original author(s) and the source, provide a link to the Creative Commons licence, and indicate if changes were made. The images or other third party material in this article are included in the article's Creative Commons licence, unless indicated otherwise in a credit line to the material. If material is not included in the article's Creative Commons licence and your intended use is not permitted by statutory regulation or exceeds the permitted use, you will need to obtain permission directly from the copyright holder. To view a copy of this licence, visit http://creativecommons.org/licenses/by/4.0/.

\section{REFERENCES}

Alexander RB, Boyer EW, Smith RA, Schwarz GE, Moore RB. 2007. The role of headwater streams in downstream water quality. J Am Water Resour As 43:41-59.

Alexander RB, Smith RA, Schwarz GE. 2000. Effect of stream channel size on the delivery of nitrogen to the Gulf of Mexico. Nature 403:758-61.

Ashkenas LR, Johnson SL, Gregory SV, Tank JL, Wollheim WM. 2004. A stable isotope tracer study of nitrogen uptake and transformation in an old-growth forest stream. Ecology 85:1725-39.

Baker DW, Bledsoe BP, Price JM. 2012. Stream nitrate uptake and transient storage over a gradient of geomorphic complexity, north-central Colorado, USA. Hydrol Process 26:3241-52.

Baker MA, Webster JR. 2017. Conservative and reactive solute dynamics. In: Lamberti GA, Hauer FR, Eds. Methods in stream ecology. London: Academic Press. p 129-45.

Battin TJ, Besemer K, Bengtsson MM, Romani AM, Packmann AI. 2016. The ecology and biogeochemistry of stream biofilms. Nat Rev Microbiol 14:251-63.

Bernot MJ, Tank JL, Royer TV, David MB. 2006. Nutrient uptake in streams draining agricultural catchments of the midwestern United States. Freshw Biol 51:499-509.

Biggs BJF, Goring DG, Nikora VI. 1998a. Subsidy and stress responses of stream periphyton to gradients in water velocity as a function of community growth form. J Phycol 34:598-607.

Biggs BJF, Nikora VI, Snelder TH. 2005. Linking scales of flow variability to lotic ecosystem structure and function. River Res Appl 21:283-98.

Biggs BJF, Stevenson RJ, Lowe RL. 1998b. A habitat matrix conceptual model for stream periphyton. Arch Hydrobiol 143:21-56.

Cardinale BJ, Palmer MA, Swan CM, Brooks SS, Poff NL. 2002. The influence of substrate heterogeneity on biofilm metabolism in a stream ecosystem. Ecology 83:412-22.

Dent CL, Grimm NB, Fisher SG. 2001. Multiscale effects of surface-subsurface exchange on stream water nutrient concentrations. J N Am Benthol Soc 20:162-81.

DIN EN ISO 11732-E23. 2005. Water quality - determination of ammonium nitrogen - method by flow analysis (CFA and FIA) and spectrometric detection (E23). Berlin: Beuth. 
DIN EN ISO 13395-D28. 1996. Water quality - determination of nitrite nitrogen and nitrate nitrogen and the sum of both by flow analysis (CFA and FIA) and spectrometric detection (D 28). Berlin: Beuth.

DIN EN ISO 15681 Part 2-D46. 2005. Water quality - determination of ortho-phosphate and total phosphorus contents by flow analysis (FIA and CFA) - Part 2: Method by continuous flow analysis (CFA) (D46). Berlin: Beuth.

Dortch Q. 1990. The interaction between ammonium and nitrate uptake in phytoplankton. Mar Ecol Prog Ser 61:183-201.

Drummond JD, Bernal S, von Schiller D, Martí E. 2016. Linking in-stream nutrient uptake to hydrologic retention in two headwater streams. Freshw Sci 35:1176-88.

EEA. 2018. CORINE Land Cover. Eropean Environmenta Agency. Available from https://land.copernicus.eu/pan-euro pean/corine-land-cover/clc2018. Accessed August 2018. CORINE Land Cover. Eropean Environmenta Agency. Available from https://land.copernicus.eu/pan-european/corine-la nd-cover/clc2018. Accessed August 2018.

Frissell CA, Liss WJ, Warren CE, Hurley MD. 1986. A hierarchical framework for stream habitat classification: viewing streams in a watershed context. Environ Manage 10:199-214.

Gordon ND, McMahon TA, Finlayson BL, Gippel CJ, Nathan RJ. 2004. Stream hydrology: an introduction for ecologists. Chichester: Wiley. p 429.

Gücker B, Boëchat IG. 2004. Stream morphology controls ammonium retention in tropical headwaters. Ecology 85:2818-27.

Gücker B, Pusch MT. 2006. Regulation of nutrient uptake in eutrophic lowland streams. Limnol Oceanogr 51:1443-53.

Hall RO, Tank JL. 2003. Ecosystem metabolism controls nitrogen uptake in streams in Grand Teton National Park, Wyoming. Limnol Oceanogr 48:1120-8.

Hall RO, Tank JL, Sobota DJ, Mulholland PJ, O’Brien JM, Dodds WK, Webster JR, Valett HM, Poole GC, Peterson BJ, Meyer JL, McDowell WH, Johnson SL, Hamilton SK, Grimm NB, Gregory SV, Dahm CN, Cooper LW, Ashkenas LR, Thomas SM, Sheibley RW, Potter JD, Niederlehner BR, Johnson LT, Helton AM, Crenshaw CM, Burgin AJ, Bernot MJ, Beaulieu JJ, Arango CP. 2009. Nitrate removal in stream ecosystems measured by $\mathrm{N}-15$ addition experiments: total uptake. Limnol Oceanogr 54:653-65.

Hanrahan BR, Tank JL, Aubeneau AF, Bolster D. 2018. Substrate-specific biofilms control nutrient uptake in experimental streams. Freshw Sci 37:456-71.

Harms TK, Grimm NB. 2008. Hot spots and hot moments of carbon and nitrogen dynamics in a semiarid riparian zone. $\mathrm{J}$ Geophys Res-Biogeo 113:G01020.

Hart DD, Finelly CM. 1999. Physical-biological coupling in streams: the pervasive effects of flow on benthic organisms. Annu Rev Ecol Syst 30:363-95.

Hildebrand M. 2005. Cloning and functional characterization of ammonium transporters from the marine diatom Cylindrotheca fusiformis (Bacillariophyceae). J Phycol 41:105-13.

Holmes RM, McClelland JW, Sigman DM, Fry B, Peterson BJ. 1998. Measuring N-15-NH4 + in marine, estuarine and fresh waters: an adaptation of the ammonia diffusion method for samples with low ammonium concentrations. Mar Chem 60:235-43.

Kemp MJ, Dodds WK. 2002. The influence of ammonium, nitrate, and dissolved oxygen concentrations on uptake, nitri- fication, and denitrification rates associated with prairie stream substrata. Limnol Oceanogr 47:1380-93.

Kobayashi S, Kagaya T. 2008. Differences in patches of retention among leaves, woods and small litter particles in a headwater stream: the importance of particle morphology. Limnology 9:47-55.

Kunz JV, Hensley R, Brase L, Borchardt D, Rode M. 2017. High frequency measurements of reach scale nitrogen uptake in a fourth order river with contrasting hydromorphology and variable water chemistry (Weisse Elster, Germany). Water Resour Res 53:328-43.

Larned ST, Nikora VI, Biggs BJF. 2004. Mass-transfer-limited nitrogen and phosphorus uptake by stream periphyton: a conceptual model and experimental evidence. Limnol Oceanogr 49:1992-2000.

Leopold WM. 1964. Fluvial processes in geomorphology. Mineola: Dover Publications. p 535.

Lipschultz F, Wofsy SC, Fox LE. 1985. The effects of light and nutrients on rates of ammonium transformation in a eutrophic river. Mar Chem 16:329-41.

Martí E, Sabater F. 1996. High variability in temporal and spatial nutrient retention in Mediterranean streams. Ecology 77:85469.

McClain ME, Boyer EW, Dent CL, Gergel SE, Grimm NB, Groffman PM, Hart SC, Harvey JW, Johnston CA, Mayorga E, McDowell WH, Pinay G. 2003. Biogeochemical hot spots and hot moments at the interface of terrestrial and aquatic ecosystems. Ecosystems 6:301-12.

McIlvin MR, Casciotti KL. 2011. Technical updates to the bacterial method for nitrate isotopic analyses. Anal Chem 83:1850-6

Mendoza-Lera C, Ribot M, Foulquier A, Martí E, Bonnineau C, Breil P, Datry T. 2019. Exploring the role of hydraulic conductivity on the contribution of the hyporheic zone to instream nitrogen uptake. Ecohydrology 12:2139.

Merbt SN, Stahl DA, Casamayor EO, Marti E, Nicol GW, Prosser JI. 2012. Differential photoinhibition of bacterial and archaeal ammonia oxidation. FEMS Microbiol Lett 327:41-6.

Montgomery DR, Buffington JM. 1997. Channel-reach morphology in mountain drainage basins. Geol Soc Am Bull 109:596-611.

Mulholland PJ, Helton AM, Poole GC, Hall RO, Hamilton SK, Peterson BJ, Tank JL, Ashkenas LR, Cooper LW, Dahm CN, Dodds WK, Findlay SEG, Gregory SV, Grimm NB, Johnson SL, McDowell WH, Meyer JL, Valett HM, Webster JR, Arango CP, Beaulieu JJ, Bernot MJ, Burgin AJ, Crenshaw CL, Johnson LT, Niederlehner BR, O'Brien JM, Potter JD, Sheibley RW, Sobota DJ, Thomas SM. 2008. Stream denitrification across biomes and its response to anthropogenic nitrate loading. Nature 452:202-246.

Mulholland PJ, Tank JL, Sanzone DM, Wollheim WM, Peterson BJ, Webster JR, Meyer JL. 2000. Nitrogen cycling in a forest stream determined by a N-15 tracer addition. Ecol Monogr 70:471-93.

Mulholland PJ, Tank JL, Webster JR, Bowden WB, Dodds WK, Gregory SV, Grimm NB, Hamilton SK, Johnson SL, Martí E, McDowell WH, Merriam JL, Meyer JL, Peterson BJ, Valett HM, Wollheim WM. 2002. Can uptake length in streams be determined by nutrient addition experiments? Results from an interbiome comparison study. J N Am Benthol Soc 2:54460. https://doi.org/10.2307/1468429 
Naldi M, Wheeler PA. 2002. N-15 measurements of ammonium and nitrate uptake by Ulva fenestrata (Chlorophyta) and Gracilaria pacifica (Rhodophyta): comparison of net nutrient disappearance, release of ammonium and nitrate, and N-15 accumulation in algal tissue. J Phycol 38:135-44.

Newbold JD, Elwood JW, Oneill RV, Vanwinkle W. 1981. Measuring nutrient spiralling in streams. Can J Fish Aquat Sci 38:860-3.

O'Brien JM, Dodds WK. 2008. Ammonium uptake and mineralization in prairie streams: chamber incubation and shortterm nutrient addition experiments. Freshw Biol 53:102-12.

O'Brien JM, Dodds WK, Wilson KC, Murdock JN, Eichmiller J. 2007. The saturation of $\mathrm{N}$ cycling in Central Plains streams: $\mathrm{N}$ 15 experiments across a broad gradient of nitrate concentrations. Biogeochemistry 84:31-49.

O'Connor BL, Hondzo M. 2008. Dissolved oxygen transfer to sediments by sweep and eject motions in aquatic environments. Limnol Oceanogr 53:566-78.

O’Neill RV, DeAngelis DL, Waide JB, Allen TFH. 1986. A hierarchical concept of ecosystems. Monographs in population biology. Princeton: Princeton University Press. p 253.

Palmer MA, Poff NL. 1997. The influence of environmental heterogeneity on patterns and processes in streams. J N Am Benthol Soc 16:169-73.

Parker SP, Bowden WB, Flinn MB, Giles CD, Arndt KA, Benes JP, Jent DG. 2018. Effect of particle size and heterogeneity on sediment biofilm metabolism and nutrient uptake scaled using two approaches. Ecosphere 9:2137.

Pastor A, Peipoch M, Canas L, Chappuis E, Ribot M, Gacia E, Riera JL, Marti E, Sabater F. 2013. Nitrogen stable isotopes in primary uptake compartments across streams differing in nutrient availability. Environ Sci Technol 47:10155-62.

Patil S, Covino TP, Packman AI, McGlynn BL, Drummond JD, Payn RA, Schumer R. 2013. Intrastream variability in solute transport: hydrologic and geomorphic controls on solute retention. J Geophys Res-Earth 118:413-22.

Peipoch M, Gacia E, Bastias E, Serra A, Proia L, Ribot M, Merbt SN, Marti E. 2016. Small-scale heterogeneity of microbial N uptake in streams and its implications at the ecosystem level. Ecology 97:1329-44.

Peters DPC, Bestelmeyer BT, Turner MG. 2007. Cross-scale interactions and changing pattern-process relationships: consequences for system dynamics. Ecosystems 10:790-6.

Peterson BJ, Wollheim WM, Mulholland PJ, Webster JR, Meyer JL, Tank JL, Marti E, Bowden WB, Valett HM, Hershey AE, McDowell WH, Dodds WK, Hamilton SK, Gregory S, Morrall DD. 2001. Control of nitrogen export from watersheds by headwater streams. Science 292:86-90.

Poole GC. 2002. Fluvial landscape ecology: addressing uniqueness within the river discontinuum. Freshw Biol 47:641-60.

Reidenbach MA, Limm M, Hondzo M, Stacey MT. 2010. Effects of bed roughness on boundary layer mixing and mass flux across the sediment-water interface. Water Resour Res 46:7530.

Ribot M, von Schiller D, Martí E. 2017. Understanding pathways of dissimilatory and assimilatory dissolved inorganic nitrogen uptake in streams. Limnol Oceanogr 62:1166-83.

Ribot M, von Schiller D, Peipoch M, Sabater F, Grimm NB, Martí E. 2013. Influence of nitrate and ammonium availability on uptake kinetics of stream biofilms. Freshw Sci 32:1155-67.

Risse-Buhl U, Anlanger C, Chatzinotas A, Noss C, Lorke A, Weitere M. 2020. Near streambed flow shapes microbial guilds within and across trophic levels in fluvial biofilms. Limnol Oceanogr 65:2261-77.

Risse-Buhl U, Anlanger C, Kalla K, Neu TR, Noss C, Lorke A, Weitere M. 2017. The role of hydrodynamics in shaping the composition and architecture of epilithic biofilms in fluvial ecosystems. Water Res 127:211-22.

Sanzone DM, Tank JL, Meyer JL, Mulholland PJ, Findlay SEG. 2001. Microbial incorporation of nitrogen in stream detritus. Hydrobiologia 464:27-35.

Simon KS, Townsend CR, Biggs BJF, Bowden WB, Frew RD. 2004. Habitat-specific nitrogen dynamics in New Zealand streams containing native or invasive fish. Ecosystems 7:77792.

Singer G, Besemer K, Schmitt-Kopplin P, Hödl I, Battin TJ. 2010. Physical heterogeneity increases biofilm resource use and its molecular diversity in stream mesocosms. Plos One 5:e9988.

Steinman AD, Lamberti GA, Leavitt PR, Uzarski DG. 2017. Biomass and pigments of benthic algae. In: Hauer FR, Lamberti GA, Eds. Methods in stream ecology. London: Academic Press. p 223-41.

Tank JL, Dodds WK. 2003. Nutrient limitation of epilithic and epixylic biofilms in ten North American streams. Freshw Biol 48:1031-49.

Tank JL, Martí E, Riis T, von Schiller D, Reisinger AJ, Dodds WK, Whiles MR, Ashkenas LR, Bowden WB, Collins SM, Crenshaw CL, Crowl TA, Griffiths NA, Grimm NB, Hamilton SK, Johnson SL, McDowell WH, Norman BM, Rosi EJ, Simon KS, Thomas SA, Webster JR. 2018. Partitioning assimilatory nitrogen uptake in streams: an analysis of stable isotope tracer additions across continents. Ecol Monogr 88:120-38.

Team RC. 2018. R: A language and environment for statistical computing. R Foundation for Statistical Computing. Vienna, Austria. https://www.R-project.org/.

Townsend CR. 1996. Concepts in river ecology: pattern and process in the catchment hierarchy. Fund Appl Limnol 131:321.

von Schiller D, Martí E, Riera JL. 2009. Nitrate retention and removal in Mediterranean streams bordered by contrasting land uses: a N-15 tracer study. Biogeosciences 6:181-96.

von Schiller D, Martí E, Riera JL, Ribot M, Marks JC, Sabater F. 2008. Influence of land use on stream ecosystem function in a Mediterranean catchment. Freshw Biol 53:2600-12.

Webster JR, Mulholland PJ, Tank JL, Valett HM, Dodds WK, Peterson BJ, Bowden WB, Dahm CN, Findlay S, Gregory SV, Grimm NB, Hamilton SK, Johnson SL, Martí E, McDowell WH, Meyer JL, Morrall DD, Thomas SA, Wollheim WM. 2003. Factors affecting ammonium uptake in streams - an interbiome perspective. Freshw Biol 48:1329-52.

Wells NS, Hakoun V, Brouyere S, Knöller K. 2016. Multi-species measurements of nitrogen isotopic composition reveal the spatial constraints and biological drivers of ammonium attenuation across a highly contaminated groundwater system. Water Res 98:363-75.

Wheeler B, Torchiano M. 2016. ImPerm: Permutation tests for linear models. $\mathrm{R}$ package version 2.1.0.

Wickham H. 2009. ggplot2: Elegant graphics for data analysis. New York: Springer.

Wiens JA. 1989. Spatial Scaling in Ecology. Funct Ecol 3:385-97. Wohl E. 2013. Fluvial geomorphology. Cambridge: Academic Press.

Wollschläger U, Attinger S, Borchardt D, Brauns M, Cuntz M, Dietrich P, Fleckenstein JH, Friese K, Friesen J, Harpke A, 
Hildebrandt A, Jäckel G, Kamjunke N, Knöller K, Kogler S, Kolditz O, Krieg R, Kumar R, Lausch A, Liess M, Marx A, Merz R, Mueller C, Musolff A, Norf H, Oswald SE, Rebmann C, Reinstorf F, Rode M, Rink K, Rinke K, Samaniego L, Vieweg M, Vogel HJ, Weitere M, Werban U, Zink M, Zacharias S. 2017. The Bode hydrological observatory: a platform for integrated, interdisciplinary hydro-ecological research within the TERENO Harz/Central German Lowland Observatory. Environ Earth Sci 76:29.

Wu JG, Levin SA. 1994. A spatial patch dynamic modeling approach to pattern and process in an annual grassland. Ecol Monogr 64:447-64. 